\title{
Leptin-A Potential Bridge between Fat Metabolism and the Brain's Vulnerability to Neuropsychiatric Disorders: A Systematic Review
}

\author{
Gilmara Gomes de Assis ${ }^{1,2, *}$ and Eugenia Murawska-Ciałowicz ${ }^{3}$ (D) \\ 1 Department of Molecular Biology, Gdansk University of Physical Education and Sports, \\ 80-336 Gdansk, Poland \\ 2 Laboratory of Behavioral Endocrinology—BELab—Brain Institute, Federal University of Rio Grande \\ do Norte, Natal 59078-970, Brazil \\ 3 Department of Physiology and Biochemistry, University School of Physical Education, \\ 51-612 Wroclaw, Poland; eugenia.murawska-cialowicz@awf.wroc.pl \\ * Correspondence: gilmara.gomesdeassis@awf.gda.pl
}

Citation: de Assis, G.G.;

Murawska-Ciałowicz, E. Leptin-A

Potential Bridge between Fat

Metabolism and the Brain's

Vulnerability to Neuropsychiatric

Disorders: A Systematic Review. J.

Clin. Med. 2021, 10, 5714. https://

doi.org/10.3390/jcm10235714

Academic Editor: Gregory A. Hand

Received: 25 October 2021

Accepted: 4 December 2021

Published: 6 December 2021

Publisher's Note: MDPI stays neutral with regard to jurisdictional claims in published maps and institutional affiliations.

Copyright: (c) 2021 by the authors. Licensee MDPI, Basel, Switzerland. This article is an open access article distributed under the terms and conditions of the Creative Commons Attribution (CC BY) license (https:// creativecommons.org/licenses/by/ $4.0 /)$.

\begin{abstract}
Background: Obesity and being overweight have been described as potential causes of neurological disorders. Leptin, a peptide expressed in fat tissue, importantly participates in energy homeostasis and storage and has recently been identified for its signaling receptors in neuronal circuits of the brain. Aim: To elucidate whether the endogenous modulation of leptin can be a protection against neuropsychiatric disorders. Method: A systematic review was performed in accordance with the PRISMA-P method, and reports of studies containing data of leptin concentrations in healthy individuals with or without obesity were retrieved from the PubMed database, using the combinations of Mesh terms for "Leptin" and "Metabolism". Results: Forty-seven randomized and non-randomized controlled trials, dating from 2000 to 2021, were included in the qualitative synthesis. Discussion and conclusions: Leptin secretion displays a stabilizing pattern that is more sensitive to a negative energy intake imbalance. Leptin levels influence body weight and fat mass as a pro-homeostasis factor. However, long-term exposure to elevated leptin levels may lead to mental/behavioral disorders related to the feeding and reward systems.
\end{abstract}

Keywords: body fat mass; energy expenditure; adipokines; eating disorders; mental health

\section{Introduction}

The implications of weight control for the development of metabolic disorders, such as cardiovascular diseases and diabetes, have been widely described in the scientific literature [1]. Genome-wide association studies have identified more than 100 genes involved in overweight and obesity phenotypes, and the complex polygenic gene-behavior interaction explains the relevance of exogenous factors in such processes [2-7]. Nevertheless, the identification of genetic components involved in energy metabolism does not account for individual needs regarding diet and/or exercise in order to achieve weight control $[8,9]$.

From a physiological perspective, a peptide hormone expressed in adipocytes, named leptin, has been suggested to function as a regulator of energy storage/expense by acting as a physiologic translator of changes in circulating glucose (GLU) levels into electrical/chemical signals in the brain [10-13]. In the brain, leptin signals exclusively through its long receptor isoform (LepRl) and participates in a number of neuroendocrine systems: for instance, sexual behavior through leptin receptor at kisspeptin neurons [14].

There are short leptin receptor isoforms present to varying degrees in almost all tissues; alteration in leptin concentrations might be associated with the GLU uptake in muscle and brown adipose tissues, and in hepatic GLU production. Furthermore, the modulatory role of leptin in the innate and adaptive immune responses implies that the regulation of leptin levels may ameliorate multiple inflammatory conditions $[15,16]$. 
Experimental research reports a selective downregulation of the LepRls, which are expressed only in a subpopulation of neurons in some hypothalamic and extra-hypothalamic regions of the central nervous system (CNS), due to high concentrations of circulating leptin [17-20]. Clinically, individuals with obesity and increased levels of leptin have been characterized as leptin-resistant; meanwhile, the loss of leptin-LepRl signaling in the brain has shown to be sufficient to promote obesity [21-23].

More recently, the influence of metabolic stressors on leptin secretion has become an important focus of research on feeding behaviors and mental disorders [24]. The finetuning of leptin-LepRls signaling, which can be affected by either too-low or too-high leptin concentrations, appears to be crucial to ensure healthy eating behaviors [25-28]. Regulation of LepRls might be the linking factor enhancing the influence of weight control on the development of psychiatric disorders [29-31].

Most studies address leptin as a potential pharmacological therapy in the control of weight gain and obesity [32,33]. However, the complexity of leptin actions and its differential interactions with other metabolic factors, both in the body and in the brain, requires a deeper understanding of the physiology of leptin in terms of weight gain/loss control [34-37].

Little is known about the physiology of leptin concentrations in the wider population since studies most likely only address individuals displaying eating and weight disorders and associated diagnoses. For this reason, whether endogenous leptin can be efficiently modulated still requires discussion. Therefore, we performed a systematic review and retrieved all the available clinical studies on leptin in the past 20 years, addressing populations with or without obesity in cohorts free of associated diagnoses, and synthesized the current knowledge on leptin physiology in the health and prevention of metabolism-related mental disorders.

\section{Methods}

In accordance with the preferred reporting items for systematic review and metaanalysis protocols (PRISMA-P) [38], to access the available literature presenting data on leptin levels (either expression or circulating concentration) in basal metabolic conditions, a double-blinded search was conducted in the PubMed and Google scholar databases and ResearchGate suggested research, concerning the following PICO strategy: P-healthy, active or sedentary individuals, with or without obesity; I-sleep and/or diet regimes; $\mathrm{C}$-healthy controls; $\mathrm{O}$-leptin and/or leptin receptor data. For this purpose, combinations of the following Mesh terms were used in an advanced search of the PubMed platform: "Leptin" AND "Metabolism" OR "Receptors, Leptin" AND "Metabolism". Searches were filtered for control trials and randomized control trials, and duplicates were removed. Google Scholar and ResearchGate were also assessed. Papers referring to SARS-CoV2 or COVID-19 were excluded. The retrieved studies, dating from 2000 to January 2021, were screened against the abstracts for inclusion criteria in a double-blinded manner.

One thousand and fifteen papers were retrieved, based on combinations of the search terms, and were screened by titles after the removal of duplicates. Four hundred and sixty-five studies were screened by titles and abstracts. The inclusion criteria comprised both controlled and randomized controlled clinical trials that presented data on leptin levels in healthy subjects with or without obesity, aged over 18 years old, and undergoing dietary and/or sleep interventions. Reviews, cohorts, brief communications, studies involving menopausal and pregnancy periods, drugs, and supplementation, as well as those addressing subpopulations with pathological conditions, were excluded. Fortyseven studies were included in the qualitative synthesis. A summary of the most frequently studied conditions and a search flowchart of the exclusion criteria are presented in Figure 1. A summary of the included studies metadata is presented in Tables 1 and 2. 
Table 1. Summary of non-randomized controlled studies' metadata.

\begin{tabular}{|c|c|c|c|c|c|c|c|}
\hline $\begin{array}{l}\text { Non-Randomized } \\
\text { Controlled Trials }\end{array}$ & Aim & Methods & Main Outcomes & Age Range & Fem $(\%)$ & $\mathrm{BMI}>25$ & BMI $<25$ \\
\hline $\begin{array}{l}\text { Sleep apnea and daytime } \\
\text { sleepiness and fatigue: } \\
\text { relation to visceral obesity, } \\
\text { insulin resistance, and } \\
\text { hypercyt [39]. }\end{array}$ & $\begin{array}{l}\text { To test whether sleep apnea } \\
\text { contributes to changes of } \\
\text { tumor necrosis factor- } \alpha \text {, } \\
\text { interleukin- } 6 \text {, and } \\
\text { leptin levels. }\end{array}$ & $\begin{array}{l}\text { Obese, sleep apneic, and control } \\
\text { subjects were investigated for leptin } \\
\text { levels and other biochemical factors, } \\
\text { and were monitored in the sleep } \\
\text { laboratory for } 4 \text { consecutive nights. }\end{array}$ & $\begin{array}{l}\text { Sleep-apneic men had higher } \\
\text { plasma concentrations of leptin than } \\
\text { non-apneic obese men or lean men, } \\
\text { who had the lowest values. }\end{array}$ & $38-49$ & 0 & 11 & 12 \\
\hline $\begin{array}{l}\text { No acute response of leptin } \\
\text { to an oral fat load in obese } \\
\text { patients and during } \\
\text { circadian rhythm in healthy } \\
\text { controls [40]. }\end{array}$ & $\begin{array}{l}\text { To elucidate the relationship } \\
\text { between postprandial leptin } \\
\text { and obesity, and the possible } \\
\text { influence of the circadian } \\
\text { rhythm on the dynamic } \\
\text { leptin response }\end{array}$ & $\begin{array}{l}\text { Leptin and insulin responses to an } \\
\text { oral fat load test were measured } \\
\text { according to the time of fat load } \\
\text { ingestion: } 0700 \mathrm{~h} \text { (diurnal (D) test) } \\
\text { or } 2200 \mathrm{~h} \text { (nocturnal (N) test) in } 9 \\
\text { normal-weight healthy men. }\end{array}$ & $\begin{array}{l}\text { Leptin concentrations were higher } \\
\text { in non-obese women than men, and } \\
\text { in obese subjects than in controls. } \\
\text { No correlation was found between } \\
\text { postprandial leptin and insulin. } \\
\text { Leptin concentrations were not } \\
\text { acutely influenced by a high fat } \\
\text { intake load. }\end{array}$ & $19-25$ & 75 & 16 & 0 \\
\hline $\begin{array}{l}\text { Insulin resistance in obesity: } \\
\text { body weight or energy } \\
\text { balance? [41]. }\end{array}$ & $\begin{array}{l}\text { To investigate the impact of } \\
\text { diet on amelioration of the } \\
\text { metabolic abnormalities } \\
\text { associated with insulin } \\
\text { resistance in obese subjects. }\end{array}$ & $\begin{array}{l}\text { Twelve healthy obese subjects } \\
\text { signed for a 6-week hypo-energetic } \\
\text { diet, then a 4-week iso-energetic } \\
\text { diet, then another 6-week } \\
\text { hypo-energetic diet again. Insulin } \\
\text { sensitivity, GLU tolerance and leptin } \\
\text { levels were assessed. }\end{array}$ & $\begin{array}{l}\text { One-third of the weight losses were } \\
\text { achieved within the first week of } \\
\text { diets. During the iso-energetic } \\
\text { weight-maintaining period, insulin } \\
\text { resistance decreased by } 43 \% \text {. Serum } \\
\text { levels of leptin and triglyceride } \\
\text { followed a similar pattern, but to a } \\
\text { lesser extent. }\end{array}$ & $38-57$ & 50 & 12 & 0 \\
\hline $\begin{array}{l}\text { Dieting is more effective in } \\
\text { reducing weight but exercise } \\
\text { is more effective in reducing } \\
\text { fat during the early phase of } \\
\text { a weight-reducing program } \\
\text { in healthy humans [42]. }\end{array}$ & $\begin{array}{l}\text { To compare the effectiveness } \\
\text { of food restriction and } \\
\text { physical activity on body } \\
\text { weight, composition and } \\
\text { concentration of serum leptin } \\
\text { in female subjects. }\end{array}$ & $\begin{array}{l}\text { Thirteen non-obese subjects signed } \\
\text { up for a two-phase crossover study } \\
\text { including 9-day hypo-energetic } \\
\text { treatments, either by food restriction } \\
\text { or increased physical activity, with a } \\
\text { 14-day washout in between and a } \\
\text { 5-day follow-up energy repletion } \\
\text { period. Parameters were established } \\
\text { before and after the two phases. }\end{array}$ & $\begin{array}{l}\text { Blood leptin levels were reduced by } \\
27.02 \% \text { and } 32.27 \% \text { after } 9 \text { days of } \\
\text { hypo- energetic treatment-diet and } \\
\text { exercise, respectively. The follow-up } \\
\text { energy repletion increased the } \\
\text { serum leptin concentration by } \sim 45 \% \\
\text { in both cases. }\end{array}$ & $22-55$ & 100 & 0 & 13 \\
\hline
\end{tabular}


Table 1. Cont.

\begin{tabular}{|c|c|c|c|c|c|c|c|}
\hline $\begin{array}{l}\text { Non-Randomized } \\
\text { Controlled Trials }\end{array}$ & Aim & Methods & Main Outcomes & Age Range & Fem $(\%)$ & $\mathrm{BMI}>25$ & BMI $<25$ \\
\hline $\begin{array}{l}\text { Differential effects of } \\
\text { high-fat and } \\
\text { high-carbohydrate } \\
\text { isoenergetic meals on } \\
\text { cardiac autonomic nervous } \\
\text { system activity in lean and } \\
\text { obese women [43]. }\end{array}$ & $\begin{array}{l}\text { To compare the effects of two } \\
\text { different isoenergetic meals on } \\
\text { the sympathetic nervous } \\
\text { system activity in lean and } \\
\text { obese women. }\end{array}$ & $\begin{array}{l}\text { Obese and nonobese subjects were } \\
\text { examined after a CHO-rich and a } \\
\text { fat-rich test meal. Blood pressure, } \\
\text { heart rate, resting energy } \\
\text { expenditure, plasma GLU, lipids, } \\
\text { insulin, leptin, and norepinephrine } \\
\text { were performed at baseline and } \\
\text { every } 1 \mathrm{~h} \text { for } 3 \mathrm{~h} \text { after the meals. }\end{array}$ & $\begin{array}{l}\text { Meal-induced thermogenesis was } \\
\text { higher after CHO-rich, compared to } \\
\text { fat-rich meals. CHO-rich meals } \\
\text { caused greater cardiac SNS } \\
\text { activation in non-obese than in } \\
\text { obese women but SNS activation } \\
\text { did not appear to influence the } \\
\text { thermic effect of the food in either } \\
\text { non-obese or obese women. }\end{array}$ & $26-45$ & 100 & 15 & 15 \\
\hline $\begin{array}{l}\text { The potential association } \\
\text { between endogenous leptin } \\
\text { and sympathovagal } \\
\text { activities in young obese } \\
\text { Japanese women [44]. }\end{array}$ & $\begin{array}{l}\text { To investigate the association } \\
\text { between leptin levels and } \\
\text { sympathovagal activities in } \\
\text { age- and height-matched } \\
\text { obese and non-obese healthy } \\
\text { young women. }\end{array}$ & $\begin{array}{l}\text { Plasma leptin concentrations were } \\
\text { measured by radioimmunoassay } \\
\text { and autonomic nervous system } \\
\text { activity was assessed during the rest } \\
\text { period by a power spectral analysis } \\
\text { of heart rate variability, and were } \\
\text { identified as very low (VLO), low } \\
\text { (LO), and high (HI). }\end{array}$ & $\begin{array}{l}\text { The global SNS index to plasma } \\
\text { leptin concentration was markedly } \\
\text { reduced in the obese compared to } \\
\text { the control group. Dynamics of BMI } \\
\text { interaction suggested a reduced } \\
\text { sympathetic responsiveness to } \\
\text { endogenous leptin production in } \\
\text { obese women, and that } 30 \% \text { of total } \\
\text { body fat might be the critical point } \\
\text { at which leptin resistance } \\
\text { is induced. }\end{array}$ & $18-22$ & 100 & 15 & 15 \\
\hline $\begin{array}{l}\text { Interactions between leptin, } \\
\text { neuropeptide-Y and insulin } \\
\text { with chronic diurnal fasting } \\
\text { during Ramadan [45]. }\end{array}$ & $\begin{array}{l}\text { To describe changes and } \\
\text { interactions between leptin, } \\
\text { neuropeptide-Y, and insulin } \\
\text { during the pattern of fasting } \\
\text { in Ramadan. }\end{array}$ & $\begin{array}{l}\text { Blood variables were measured at } \\
\text { 1:00-2:00 p.m. during baseline and } \\
\text { on days } 14 \text { and } 28 \text { of Ramadan } \\
\text { fasting-abstinence from all food or } \\
\text { drink, including water and chewing } \\
\text { gum, from dawn to sunset. }\end{array}$ & $\begin{array}{l}\text { Long-term fasting with interrupted } \\
\text { nocturnal eating is associated with } \\
\text { significant elevations in serum } \\
\text { leptin and insulin and reduction in } \\
\text { serum neuropeptide-Y. Changes in } \\
\text { leptin appeared to be mediated by } \\
\text { insulin. Neuropeptide-Y changes } \\
\text { were independent of leptin } \\
\text { or insulin. }\end{array}$ & $20-24$ & 100 & & 46 \\
\hline
\end{tabular}


Table 1. Cont.

\begin{tabular}{|c|c|c|c|c|c|c|c|}
\hline $\begin{array}{l}\text { Non-Randomized } \\
\text { Controlled Trials }\end{array}$ & Aim & Methods & Main Outcomes & Age Range & Fem $(\%)$ & BMI > 25 & BMI $<25$ \\
\hline $\begin{array}{l}\text { Extra-adipocyte leptin } \\
\text { release in human obesity } \\
\text { and its relation to } \\
\text { sympathoadrenal } \\
\text { function [46]. }\end{array}$ & $\begin{array}{l}\text { To measure total and regional } \\
\text { norepinephrine spillover, } \\
\text { epinephrine secretion rate, and } \\
\text { extra-adipocyte leptin release } \\
\text { in lean and obese subjects. }\end{array}$ & $\begin{array}{l}\text { Total and regional extra-adipocyte } \\
\text { leptin release was measured in } \\
\text { obese and nonobese men by arterial } \\
\text { and central venous catheterization. } \\
\text { Because the plasma clearance of } \\
\text { leptin is primarily by renal removal, } \\
\text { whole-body leptin release to plasma } \\
\text { from renal plasma leptin extraction } \\
\text { was estimated. }\end{array}$ & $\begin{array}{l}\text { Whole-body leptin release was } \\
1950 \text { SE } 643 \mathrm{ng} / \mathrm{min} \text { in obese men } \\
\text { and } 382 \mathrm{SE} 124 \mathrm{ng} / \mathrm{min} \text { in } \\
\text { non-obese men. A large } \\
\text { contribution of brain leptin release } \\
\text { to the plasma leptin pool was found } \\
\text { ( }>40 \% \text { whole body leptin release), } \\
\text { with greater leptin release in obese } \\
\text { than in non-obese men. }\end{array}$ & $35-50$ & 0 & 20 & 22 \\
\hline $\begin{array}{l}\text { Adiponectin's relationship } \\
\text { with lipid metabolism is } \\
\text { independent of body fat } \\
\text { mass: Evidence from both } \\
\text { cross-sectional and } \\
\text { intervention studies [47]. }\end{array}$ & $\begin{array}{l}\text { To investigate the relation } \\
\text { between plasma adiponectin } \\
\text { and leptin levels, insulin } \\
\text { sensitivity, and serum lipids in } \\
\text { a cross-sectional study. }\end{array}$ & $\begin{array}{l}\text { Plasma adiponectin and leptin } \\
\text { levels, insulin sensitivity, and serum } \\
\text { lipids were analyzed in } 242 \\
\text { non-obese and obese subjects } \\
\text { participating in a 6-12-month } \\
\text { weight-loss program. }\end{array}$ & $\begin{array}{l}\text { Plasma adiponectin, but not leptin } \\
\text { levels, were correlated with insulin } \\
\text { sensitivity, insulin sensitivity index, } \\
\text { HDL cholesterol, and triglycerides. } \\
\text { Plasma adiponectin increased and } \\
\text { plasma leptin decreased after } \\
\text { weight loss, and the changes were } \\
\text { correlated with subjects' BMI. }\end{array}$ & $17-70$ & 64 & 95 & 107 \\
\hline $\begin{array}{l}\text { A high-protein diet induced } \\
\text { sustained reductions in } \\
\text { appetite, ad libitum caloric } \\
\text { intake, and body weight } \\
\text { despite compensatory } \\
\text { changes in diurnal plasma } \\
\text { leptin and ghrelin } \\
\text { concentrations [48]. }\end{array}$ & $\begin{array}{l}\text { To test whether increasing the } \\
\text { protein content while } \\
\text { maintaining the carbohydrate } \\
\text { content in the diet lowers body } \\
\text { weight by decreasing appetite } \\
\text { and spontaneous } \\
\text { caloric intake. }\end{array}$ & $\begin{array}{c}\text { Caloric intake, appetite, } \\
\text { anthropometry, and leptin levels } \\
\text { were measured in obese subjects } \\
\text { undergoing a higher-fat, a lower-fat, } \\
\text { and an ad libitum diet over } 12 \\
\text { weeks. The AUC of plasma insulin } \\
\text { vs. time, leptin, and ghrelin } \\
\text { were measured. }\end{array}$ & $\begin{array}{l}\text { Satiety was markedly increased } \\
\text { with the isocaloric high-protein diet, } \\
\text { despite an unchanged leptin AUC, } \\
\text { and spontaneous energy intake } \\
\text { decreased with the ad libitum } \\
\text { high-protein diet, despite a } \\
\text { decreased leptin AUC and increased } \\
\text { ghrelin AUC. An increase in dietary } \\
\text { protein intake from } 15 \% \text { to } 30 \% \text { of } \\
\text { energy at a constant carbohydrate } \\
\text { level produces a decrease in ad } \\
\text { libitum caloric intake that appears } \\
\text { to be mediated by increased leptin } \\
\text { sensitivity in the CNS, resulting in } \\
\text { weight loss. }\end{array}$ & $27-62$ & 63 & 19 & 0 \\
\hline
\end{tabular}


Table 1. Cont.

\begin{tabular}{|c|c|c|c|c|c|c|c|}
\hline $\begin{array}{l}\text { Non-Randomized } \\
\text { Controlled Trials }\end{array}$ & Aim & Methods & Main Outcomes & Age Range & Fem $(\%)$ & BMI > 25 & BMI $<25$ \\
\hline $\begin{array}{l}\text { Determinants of coronary } \\
\text { flow velocity reserve in } \\
\text { healthy young men [49]. }\end{array}$ & $\begin{array}{l}\text { To identify the risk markers } \\
\text { for attenuated coronary flow } \\
\text { velocity reserve that exist in } \\
\text { healthy young men without } \\
\text { evident atherosclerotic } \\
\text { risk factors. }\end{array}$ & $\begin{array}{l}\text { Echocardiography and } \\
\text { ergospirometry sessions were } \\
\text { conducted, and coronary blood flow } \\
\text { was measured in non-obese men. } \\
\text { Anthropometric measures and the } \\
\text { regulation of fat metabolism were } \\
\text { assessed by determining the } \\
\text { adiponectin and leptin levels. }\end{array}$ & $\begin{array}{l}\text { There was no relationship between } \\
\text { coronary flow velocity reserve and } \\
\text { serum lipids or body mass index. It } \\
\text { was concluded that abdominal fat } \\
\text { accumulation and low aerobic } \\
\text { fitness are independently associated } \\
\text { with coronary flow velocity reserve } \\
\text { in men. }\end{array}$ & $19-36$ & 0 & 0 & 37 \\
\hline $\begin{array}{c}\text { PPAR } \gamma \text { activity in } \\
\text { subcutaneous abdominal fat } \\
\text { tissue and fat mass gain } \\
\text { during short-term } \\
\text { overfeeding [50]. }\end{array}$ & $\begin{array}{l}\text { To investigate whether initial } \\
\text { subcutaneous PPAR } \gamma \text { activity } \\
\text { is related to fat mass } \\
\text { generation during } \\
\text { overfeeding. }\end{array}$ & $\begin{array}{l}\text { Fourteen healthy non-obese subjects } \\
\text { were overfed with a diet supplying } \\
50 \% \text { more energy than the baseline } \\
\text { energy requirements for } 14 \text { days. } \\
\text { Blood analyses of leptin, insulin and } \\
\text { GLU, as well as mRNA expression } \\
\text { of PPARg1, PPARg2, aP2 and UCP2, } \\
\text { in fasting subcutaneous abdominal } \\
\text { fat were performed. }\end{array}$ & $\begin{array}{l}\text { Basal levels of Initial PPARg1 and 2, } \\
\text { aP2 and UCP2 mRNAs were not } \\
\text { related to fat gain. Changes in } \\
\text { PPARg1, PPARg2 and aP2 mRNAs } \\
\text { were positively related to changes in } \\
\text { plasma leptin. }\end{array}$ & $20-28$ & 100 & 0 & 14 \\
\hline $\begin{array}{l}\text { The consequences of } \\
\text { omitting or adding a meal in } \\
\text { males, regarding body } \\
\text { composition, food intake, } \\
\text { and metabolism [51]. }\end{array}$ & $\begin{array}{l}\text { To investigate the consequence } \\
\text { on body composition and } \\
\text { related biological and } \\
\text { metabolic parameters of } \\
\text { omitting or adding a meal. }\end{array}$ & $\begin{array}{l}\text { Twenty-four nonobese subjects were } \\
\text { recruited to either omit or add a } \\
\text { fourth meal during a 28-day period; } \\
\text { blood parameters were tested from } \\
\text { lunch to the spontaneously } \\
\text { requested dinner in each condition. }\end{array}$ & $\begin{array}{l}\text { Omitting a meal was followed by } \\
\text { increases in fat mass and } \\
\text { late-evening leptin concentration. } \\
\text { Adding a meal had no effect. In } \\
\text { both groups, the change in energy } \\
\text { content of the fourth eating regime } \\
\text { was correlated with the change } \\
\text { in adiposity. }\end{array}$ & $19-25$ & & & 23 \\
\hline $\begin{array}{l}\text { Ramadan fasting's effect on } \\
\text { plasma leptin, adiponectin } \\
\text { concentrations, and body } \\
\text { composition in trained } \\
\text { young men [52]. }\end{array}$ & $\begin{array}{l}\text { To evaluate the effect of } \\
\text { Ramadan fasting on } \\
\text { parameters of insulin } \\
\text { resistance in trained athletes at } \\
\text { rest and after aerobic exercise. }\end{array}$ & $\begin{array}{l}\text { Nonobese subjects performed a } \\
\text { progressive cycle-ergometer test one } \\
\text { week before, after the first week, } \\
\text { and during the fourth week of } \\
\text { Ramadan, with biochemical } \\
\text { analyses of GLU, cholesterol, HDL } \\
\text { cholesterol, triglycerides, creatinine, } \\
\text { and serum proteins, as well as } \\
\text { insulin, leptin, and adiponectin. }\end{array}$ & $\begin{array}{l}\text { Ramadan fasting was associated } \\
\text { with a reduction in body mass and } \\
\text { body fat without changes to leptin } \\
\text { or adiponectin levels. }\end{array}$ & $18-22$ & 0 & & 9 \\
\hline
\end{tabular}


Table 1. Cont.

\begin{tabular}{|c|c|c|c|c|c|c|c|}
\hline $\begin{array}{l}\text { Non-Randomized } \\
\text { Controlled Trials }\end{array}$ & Aim & Methods & Main Outcomes & Age Range & Fem $(\%)$ & BMI $>25$ & $\mathrm{BMI}<25$ \\
\hline $\begin{array}{c}\text { Improvements in coronary } \\
\text { heart disease risk indicators } \\
\text { by alternate-day fasting } \\
\text { involving adipose tissue } \\
\text { modulations [53]. }\end{array}$ & $\begin{array}{l}\text { To examine the effects of } \\
\text { alternate-day fasting on } \\
\text { adipokine profile, body } \\
\text { composition, and coronary } \\
\text { heart disease risk indicators in } \\
\text { obese adults. }\end{array}$ & $\begin{array}{l}\text { Obese subjects signed for a } 10 \text {-week } \\
\text { trial with the following consecutive } \\
\text { diet phases: } 2 \text {-week baseline control, } \\
\text { 4-week alternate-day fasting with } \\
\text { controlled feeding, and 4-week } \\
\text { alternate-day fasting with } \\
\text { self-selected feeding. }\end{array}$ & $\begin{array}{l}\text { Leptin and resistin concentrations } \\
\text { were reduced by } 21 \text { and } 23 \% \text {, } \\
\text { respectively, after } 8 \text { weeks of } \\
\text { treatment. Lower triacylglycerol } \\
\text { concentrations were associated with } \\
\text { augmented adiponectin and } \\
\text { reduced leptin concentrations } \\
\text { post-treatment. }\end{array}$ & $40-52$ & 75 & 12 & 0 \\
\hline $\begin{array}{l}\text { Regulation of energy balance } \\
\text { during long-term physical } \\
\text { inactivity, induced by bed } \\
\text { rest, with and without } \\
\text { exercise training [ } 54] .\end{array}$ & $\begin{array}{l}\text { To determine the long-term } \\
\text { effects of physical inactivity on } \\
\text { energy balance regulation and } \\
\text { to test the effect of exercise } \\
\text { training on energy balance } \\
\text { adjustment to physical } \\
\text { inactivity. }\end{array}$ & $\begin{array}{l}\text { Nonobese subjects were divided } \\
\text { into two groups: } 1 \text {-accomplished a } \\
\text { strict } 60 \text {-day bed rest, } 2-\mathrm{a} \\
\text { combined aerobic/resistance } \\
\text { exercise training concomitantly with } \\
\text { bed rest. Body composition, } \\
\text { spontaneous energy intake, hunger, } \\
\text { total energy expenditure, and } \\
\text { fasting gut hormones } \\
\text { were measured. }\end{array}$ & $\begin{array}{l}\text { Leptin levels did not change in both } \\
\text { groups and no group effect was } \\
\text { observed. Leptin levels were } \\
\text { strongly associated with fat mass. } \\
\text { Fasting leptin levels, adjusted for fat } \\
\text { mass, negatively correlated with the } \\
\text { spontaneous energy intake after } \\
\text { the program. }\end{array}$ & $30-40$ & 100 & 0 & 16 \\
\hline $\begin{array}{l}\text { Relationships between } \\
\text { serum adiponectin, leptin } \\
\text { concentrations and bone } \\
\text { mineral density, and bone } \\
\text { biochemical markers in } \\
\text { Chinese women [55]. }\end{array}$ & $\begin{array}{l}\text { To investigate whether serum } \\
\text { adipocytokines concentrations } \\
\text { are associated with bone } \\
\text { mineral density and bone } \\
\text { turnover markers. }\end{array}$ & $\begin{array}{c}\text { Serum adiponectin, leptin } \\
\text { concentrations, bone turnover } \\
\text { biochemical markers, and bone } \\
\text { mineral density were analyzed in } \\
265 \text { non-obese } \\
\text { premenopausal women. }\end{array}$ & $\begin{array}{l}\text { Adiponectin and leptin were the } \\
\text { main circulating peptides secreted } \\
\text { by the adipose tissue. There were no } \\
\text { significant correlations between } \\
\text { leptin concentrations and } \\
\text { bone-specific alkaline phosphatase } \\
\text { in premenopausal and } \\
\text { postmenopausal women. }\end{array}$ & $26-44$ & 100 & 0 & 265 \\
\hline
\end{tabular}


Table 1. Cont.

\begin{tabular}{|c|c|c|c|c|c|c|c|}
\hline $\begin{array}{l}\text { Non-Randomized } \\
\text { Controlled Trials }\end{array}$ & Aim & Methods & Main Outcomes & Age Range & Fem $(\%)$ & $\mathrm{BMI}>25$ & BMI $<25$ \\
\hline $\begin{array}{l}\text { Monitoring the diurnal } \\
\text { rhythm of circulating } \\
\text { nicotinamide } \\
\text { phosphoribosyltransferase } \\
\text { (Nampt/visfatin/PBEF): } \\
\text { impact of sleep loss and its } \\
\text { relationship with glucose } \\
\text { metabolism [56]. }\end{array}$ & $\begin{array}{l}\text { To examine the } 24-h \text { profile of } \\
\text { the serum Nampt in humans } \\
\text { under conditions of sleep and } \\
\text { sleep deprivation, and to } \\
\text { relate the Nampt pattern to } \\
\text { morning postprandial } \\
\text { GLU metabolism. }\end{array}$ & $\begin{array}{l}\text { Non-obese subjects participated in } \\
\text { two } 24 \text {-h lab sessions starting at } \\
1800 \mathrm{~h} \text {, including either a regular } 8 \mathrm{~h} \\
\text { per night sleep or continuous } \\
\text { wakefulness. Serum Nampt and } \\
\text { leptin were measured at 1.5- to 3-h } \\
\text { intervals. In the morning, plasma } \\
\text { GLU and serum insulin responses to } \\
\text { standardized breakfast intake } \\
\text { were determined. }\end{array}$ & $\begin{array}{l}\text { Under regular sleep-wake } \\
\text { conditions, Nampt levels displayed } \\
\text { a pronounced diurnal rhythm, } \\
\text { peaking during the early afternoon, } \\
\text { which was inverse to leptin profiles, } \\
\text { which peaked in the early night. } \\
\text { When subjects stayed awake, the } \\
\text { Nampt rhythm was preserved but } \\
\text { the phase advanced by about } 2 \mathrm{~h} \text {. }\end{array}$ & $20-24$ & 0 & & 14 \\
\hline $\begin{array}{l}\text { Changes in serum } \\
\text { aldosterone, associated with } \\
\text { changes in obesity-related } \\
\text { factors in normotensive } \\
\text { overweight and obese young } \\
\text { adults [57]. }\end{array}$ & $\begin{array}{l}\text { To verify whether reductions } \\
\text { in serum aldosterone are } \\
\text { associated with favorable } \\
\text { changes in obesity-related } \\
\text { factors in normotensive } \\
\text { overweight/obese } \\
\text { young adults. }\end{array}$ & $\begin{array}{l}\text { Obese subjects in a clinical trial, } \\
\text { examining the effects of a 1-year diet } \\
\text { and physical activity intervention } \\
\text { with or without sodium restriction } \\
\text { on vascular health. Bodyweight, } \\
\text { serum aldosterone, } 24 \text {-h sodium and } \\
\text { potassium excretion and } \\
\text { obesity-related factors were } \\
\text { measured at baseline, } 6,12 \text { and } \\
24 \text { months. }\end{array}$ & $\begin{array}{l}\text { Decreases in aldosterone were } \\
\text { found to be associated with } \\
\text { decreases in leptin, insulin, } \\
\text { homeostasis assessment of insulin } \\
\text { resistance, heart rate, tonic cardiac } \\
\text { sympathovagal balance, and } \\
\text { increases in adiponectin. }\end{array}$ & $20-45$ & 80 & 285 & 0 \\
\hline $\begin{array}{l}\text { The role of leptinemia as a } \\
\text { mediator of inflammation in } \\
\text { obese adults [58]. }\end{array}$ & $\begin{array}{l}\text { To investigate the role of } \\
\text { leptinemia, adjusted by } \\
\text { tertiles, on the inflammatory } \\
\text { state in obese adults, } \\
\text { according to obesity degree. }\end{array}$ & $\begin{array}{l}\text { Obese subjects assessed for } \\
\text { inflammation markers such as } \\
\text { leptin, adiponectin, and the } \\
\text { plasminogen activator inhibitor } \\
\text { were grouped according to the } \\
\text { adjusted tertiles of the leptin levels. }\end{array}$ & $\begin{array}{l}\text { A negative correlation between } \\
\text { leptin concentrations and the } \\
\text { adiponectin/leptin ratio, and a } \\
\text { positive correlation with the } \\
\text { leptin/adiponectin ratio. The ratios } \\
\text { were decreased and increased, } \\
\text { respectively, according to } \\
\text { obesity degree. }\end{array}$ & $30-58$ & 72 & 43 & 0 \\
\hline
\end{tabular}


Table 1. Cont.

\begin{tabular}{|c|c|c|c|c|c|c|c|}
\hline $\begin{array}{l}\text { Non-Randomized } \\
\text { Controlled Trials }\end{array}$ & Aim & Methods & Main Outcomes & Age Range & Fem $(\%)$ & $\mathrm{BMI}>25$ & BMI $<25$ \\
\hline $\begin{array}{l}\text { Metabolic adaptation to } \\
\text { caloric restriction and } \\
\text { subsequent refeeding: the } \\
\text { Minnesota starvation } \\
\text { experiment revisited [59]. }\end{array}$ & $\begin{array}{l}\text { To address the variance and } \\
\text { kinetics of adaptive } \\
\text { thermogenesis, its associations } \\
\text { with body composition in the } \\
\text { context of endocrine } \\
\text { determinants, and its effect on } \\
\text { weight regain. }\end{array}$ & $\begin{array}{l}\text { Non-obese subjects accomplished } \\
\text { an over-feeding ( } 1 \text { week at }+50 \% \text { of } \\
\text { energy needs) followed by a caloric } \\
\text { restriction ( } 3 \text { weeks at } 50 \% \text { of energy } \\
\text { needs), and refeeding diet ( } 2 \text { weeks } \\
\text { at }+50 \% \text { of energy needs). Adaptive } \\
\text { thermogenesis and its determinants } \\
\text { were measured, together with body } \\
\text { composition, whole-body MRI, } \\
\text { isotope dilution, and nitrogen and } \\
\text { fluid balances. }\end{array}$ & $\begin{array}{l}\text { Caloric restriction reduced fat mass } \\
\text { and fat-free mass and led to } \\
\text { reductions in energy expenditure, } \\
\text { heart rate, blood pressure, creatinine } \\
\text { clearance, the activity of the } \\
\text { sympathetic nervous system, } \\
\text { plasma leptin, insulin, adiponectin, } \\
\text { T3, and testosterone. Sympathetic } \\
\text { nervous system activity, plasma } \\
\text { leptin, ghrelin, and T3 and their } \\
\text { changes were not related to } \\
\text { adaptive thermogenesis. }\end{array}$ & $20-37$ & 0 & & 32 \\
\hline $\begin{array}{l}\text { Energy homeostasis and } \\
\text { appetite-regulating } \\
\text { hormones as predictors of } \\
\text { weight loss in men and } \\
\text { women [60]. }\end{array}$ & $\begin{array}{l}\text { To characterize plasma leptin, } \\
\text { ghrelin and adiponectin } \\
\text { concentrations in overweight } \\
\text { and obese males and females, } \\
\text { and to determine whether } \\
\text { baseline concentrations of } \\
\text { these hormones predict } \\
\text { weight loss. }\end{array}$ & $\begin{array}{l}\text { Subjects were assessed for } \\
\text { biochemical analyses pre- and } \\
\text { post-3- and 6-month participation in } \\
\text { a weight-loss program. Baseline } \\
\text { concentrations of leptin, adiponectin } \\
\text { and ghrelin were determined. }\end{array}$ & $\begin{array}{l}\text { Females had higher baseline } \\
\text { concentrations of leptin, } \\
\text { adiponectin and ghrelin, as well as } \\
\text { ratios of leptin:adiponectin and } \\
\text { leptin:ghrelin. Additionally in } \\
\text { females, a higher baseline total } \\
\text { ghrelin predicted greater weight } \\
\text { loss and a higher ratio of } \\
\text { leptin:ghrelin predicted weight gain } \\
\text { at six months. A higher } \\
\text { leptin:ghrelin ratio is a predictor of } \\
\text { weight loss failure in females. }\end{array}$ & $18-60$ & 55 & 119 & 0 \\
\hline
\end{tabular}

$\mathrm{CHO}$, carbohydrate; AUC, area under the curve; BMI, body mass index; PPAR, peroxisome proliferator-activated receptor. 
Table 2. Summary of non-controlled studies' metadata.

\begin{tabular}{|c|c|}
\hline $\begin{array}{l}\text { Randomized and } \\
\text { Quasi-Randomized } \\
\text { Controlled Trials }\end{array}$ & Aim \\
\hline $\begin{array}{l}\text { Plasma leptin in moderately } \\
\text { obese men: independent } \\
\text { effects of weight loss and } \\
\text { aerobic exercise [61]. }\end{array}$ & $\begin{array}{l}\text { To describe the independent } \\
\text { effects of weight loss and } \\
\text { exercise on plasma } \\
\text { leptin levels. }\end{array}$ \\
\hline
\end{tabular}

aerobic exercise [61].
Fifty-two sedentary obese men were assigned for 12 weeks to one of the following conditions: (1) control, (2) diet-induced weight loss, (3) exercise-weight stable, and (4) exercise-induced weight loss. Diets consisted of $55-60 \%$ carbohydrate $15-20 \%$ protein and $20-25 \%$ fat.
To determine whether leptin serves as an indicator of

Twenty-four-hour leptin levels respond to cumulative short-term energy imbalance and predict subsequent intake [62].

\section{short-term energy balance by} measuring the acute effects of small manipulations in energy intake on leptin levels in normal individuals.
Four consecutive dietary treatments of 3 days each were applied to 6 healthy non-obese subjects, and leptin levels were serially measured throughout the study.

\section{Main Outcomes}

Plasma leptin and BMI did not

change in the control or the

weight-stable groups. Diet and exercise similarly decreased plasma leptin after weight loss. Exercise in the absence of weight loss did not alter leptin levels. Changes in leptin correlated with changes in total and subcutaneous, but not in visceral, adipose tissues.

During washout after the underfeeding period, leptin levels were $88 \%$ of the eucaloric baseline, compared with $135 \%$ following overfeeding. Leptin levels did not return to baseline with the washout diet and were restored only after cross-over to the complementary diet treatment. Ad libitum intake changes correlated with changes in leptin levels.

Nine healthy non-obese adults signed for an 8-day regimen in one of the following isocaloric diets containing $15 \%$ protein: A-high glycemic index (GI) CHO, 30\% fat:

A high-glycemic-index carbohydrate diet alters the diurnal rhythm of leptin but not insulin concentrations [63].
To determine whether post-prandial and diurnal patterns of leptin levels were altered by the type of diet amount of fat.
B-low GI CHO, 30\%fat; C-high

GI CHO, 20\% fat; and D-low GI $\mathrm{CHO}, 20 \%$ fat. Serum GLU, insulin, and leptin levels were measured for $24 \mathrm{~h}$ on day 8 , and on day 9 during
Age Range $\quad$ Fem (\%) $\quad$ BMI $>25 \quad$ BMI $<25$
Diets with HGI altered the serum leptin diurnal pattern, causing a rise in leptin beginning at 13:00 $\mathrm{h}$. The area under the curve for leptin between 12:30 and 24:00 $\mathrm{h}$ in these diets was $17 \%$ greater. During the OGTT, leptin concentrations were similar in all diets. an OGTT. 
Table 2. Cont.

Randomized and

Quasi-Randomized

Controlled Trials

Effect of high-fat meals and fatty acid saturation on postprandial levels of the hormones ghrelin and leptin in healthy men [64].
To investigate whether high-fat meals, which differed in saturated fatty acid content, acutely modified these hormones. experienced a high-fat test meal ( $71 \%$ of energy as fat) as breakfast with either a high or low saturated:unsaturated fatty acid ratio on two occasions. Fasting and postprandial measurements of ghrelin, leptin and insulin were performed over $6 \mathrm{~h}$, and at 10 and $24 \mathrm{~h}$ following a fat-exclusion lunch, snack, and dinner.
Eighteen nonobese subjects
There was no significant effect of fatty meals (either saturated or unsaturated) on ghrelin over $6 \mathrm{~h}$. Leptin decreased in response to both high-fat meals. There was no correlation between ghrelin or leptin and circulating insulin. Increasing dietary saturated fatty acids had no deleterious effects on leptin or total ghrelin.
Hormonal responses to a fast-food meal compared with nutritionally comparable meals of different composition [65].

To compare differences in the acute metabolic response to fast food and "healthy" meal with a similar composition.
Obese subjects were given a standard breakfast followed by one of the three lunches at noon: a fast-food meal; an organic beef meal; and a turkey sandwich made with organic foods and an organic orange juice. Blood parameters were measured every $30 \mathrm{~min}$ over a period of $6 \mathrm{~h}$.

Leptin levels, whether expressed as a percent of baseline or absolute values, showed no significant pattern of change over the 6-h postprandial period.

Nonobese subjects underwent two 8-week ad libitum diet periods for weight maintenance with either

Impact of reduced meal frequency, without caloric restriction on glucose regulation in healthy,

normal-weight middle-aged men and women [66].
To evaluate the influence of reduced meal frequency, without a reduction in energy intake, on GLU metabolism in normal-weight, healthy male and female subjects.
Diet had no significant effects on morning plasma glucagon, leptin, adiponectin, resistin, and BDNF. three meals/day (breakfast, lunch, and dinner) or one meal/day (during a 4-h period in the early evening; 4:00 to 8:00 p.m.), with an 11-week washout period. Energy metabolism was evaluated

throughout the study by morning OGTT, GLU, insulin, glucagon,

leptin, ghrelin, adiponectin, resistin, and BDNF levels. 
Table 2. Cont.

\begin{tabular}{|c|c|c|c|c|c|c|c|}
\hline $\begin{array}{l}\text { Randomized and } \\
\text { Quasi-Randomized } \\
\text { Controlled Trials }\end{array}$ & Aim & Methods & Main Outcomes & Age Range & Fem $(\%)$ & BMI > 25 & BMI $<25$ \\
\hline $\begin{array}{l}\text { Specific insulin sensitivity } \\
\text { and leptin responses to a } \\
\text { nutritional treatment of } \\
\text { obesity, via a combination of } \\
\text { energy restriction and fatty } \\
\text { fish intake [67]. }\end{array}$ & $\begin{array}{l}\text { To investigate whether the } \\
\text { inclusion of three fatty fish } \\
\text { servings per week within a } \\
\text { hypocaloric diet may have } \\
\text { specific health effects on } \\
\text { insulin and leptin functions. }\end{array}$ & $\begin{array}{l}\text { Obese subjects were assigned to a } \\
\text { control, a fish or a fatty fish-based } \\
\text { diet, with a }-30 \% \text { total energy } \\
\text { expenditure caloric restriction over } \\
\text { an 8-week period. Anthropometry, } \\
\text { body composition, lipid profile, } \\
\text { leptin and insulin values were } \\
\text { measured pre- and } \\
\text { post-intervention. }\end{array}$ & $\begin{array}{l}\text { A decrease in leptin was only } \\
\text { observed after the fish-enriched } \\
\text { diets. There was a positive } \\
\text { correlation between insulin and } \\
\text { leptin decreases. Sixteen percent of } \\
\text { the variability in leptin changes } \\
\text { could be explained by the HOMA } \\
\text { index change and the type of diet. }\end{array}$ & $29-45$ & 44 & 32 & 0 \\
\hline $\begin{array}{l}\text { Sleep curtailment, } \\
\text { accompanied by an } \\
\text { increased intake of calories } \\
\text { from snacks [68]. }\end{array}$ & $\begin{array}{l}\text { To test whether the } \\
\text { curtailment of human sleep } \\
\text { could promote excessive } \\
\text { energy intake. }\end{array}$ & $\begin{array}{l}\text { Obese subjects were confined in a } \\
\text { sleep laboratory for } 14 \text {-day stays } \\
\text { with ad libitum access to palatable } \\
\text { food and either } 5.5-\mathrm{h} \text { or } 8.5-\mathrm{h} \\
\text { bedtimes. Calories consumed } \\
\text { during each bedtime condition, total } \\
\text { energy expenditure, and } 24-\mathrm{h} \\
\text { profiles of serum leptin and ghrelin } \\
\text { were analyzed. }\end{array}$ & $\begin{array}{l}\text { No significant differences were } \\
\text { found in serum leptin and ghrelin } \\
\text { between the two sleep conditions. } \\
\text { Twenty-four-hour leptin } \\
\text { concentrations increased in a similar } \\
\text { fashion at the end of the 5.5- and } \\
\text { 8.5-h bedtime interventions. }\end{array}$ & $35-45$ & 45 & 11 & 0 \\
\hline $\begin{array}{l}\text { High protein intake reduced } \\
\text { intrahepatocellular lipid } \\
\text { deposition in humans [69]. }\end{array}$ & $\begin{array}{l}\text { To assess the effect of high } \\
\text { protein intake on high-fat } \\
\text { diet-induced IHCL } \\
\text { accumulation and insulin } \\
\text { sensitivity in healthy } \\
\text { young men. }\end{array}$ & $\begin{array}{l}\text { Non-obese subjects crossover after } 4 \\
\text { days on a hypercaloric high-fat diet; } \\
\text { a hypercaloric high-fat, high-protein } \\
\text { diet; and a control, isocaloric diet. } \\
\text { Fasting metabolism analyses were } \\
\text { performed at the end of the fourth } \\
\text { day of each period, and the } \\
\text { expression of key lipogenic genes } \\
\text { was assessed in subcutaneous } \\
\text { adipose tissue biopsies. }\end{array}$ & $\begin{array}{l}\text { The high-fat diet and hypercaloric } \\
\text { high-fat high-protein diet } \\
\text { significantly increased plasma leptin } \\
\text { concentrations. }\end{array}$ & $22-26$ & 0 & & 10 \\
\hline
\end{tabular}


Table 2. Cont.

\begin{tabular}{|c|c|c|c|c|c|c|c|}
\hline $\begin{array}{l}\text { Randomized and } \\
\text { Quasi-Randomized } \\
\text { Controlled Trials }\end{array}$ & Aim & Methods & Main Outcomes & Age Range & Fem $(\%)$ & $\mathrm{BMI}>25$ & BMI $<25$ \\
\hline $\begin{array}{l}\text { Carbohydrate restriction } \\
\text { (with or without additional } \\
\text { dietary cholesterol, provided } \\
\text { by eggs) reduces insulin } \\
\text { resistance and plasma leptin } \\
\text { without modifying appetite } \\
\text { hormones in adult men [70]. }\end{array}$ & $\begin{array}{l}\text { To evaluate the effects of } \\
\text { additional dietary cholesterol } \\
\text { and protein, provided by } \\
\text { whole eggs while following } \\
\text { carbohydrate-restricted diets, } \\
\text { on insulin resistance and } \\
\text { appetite hormones. }\end{array}$ & $\begin{array}{l}\text { Obese subjects were allocated to the } \\
\text { following 12-week regimes: egg } \\
\text { ( } 640 \mathrm{mg} / \mathrm{d} \text { additional dietary } \\
\text { cholesterol) or placebo }(0 \mathrm{mg} / \mathrm{d} \\
\text { additional dietary cholesterol) while } \\
\text { following carbohydrate-restricted } \\
\text { diets. }\end{array}$ & $\begin{array}{c}\text { There were significant reductions in } \\
\text { fasting insulin and fasting leptin } \\
\text { concentrations for both groups, } \\
\text { which were correlated with the } \\
\text { reductions in body weight and } \\
\text { body fat. }\end{array}$ & $40-70$ & 0 & 31 & 0 \\
\hline $\begin{array}{l}\text { Serum leptin levels in obese } \\
\text { males during over- and } \\
\text { underfeeding [71]. }\end{array}$ & $\begin{array}{l}\text { To test whether leptin } \\
\text { responds to short-term } \\
\text { changes in energy balance in } \\
\text { obese and lean males. }\end{array}$ & $\begin{array}{l}\text { Obese subjects were signed to four } \\
\text { consecutive dietary treatment } \\
\text { periods of } 3 \text { days each: eucaloric } \\
\text { diet, followed by periods of } \\
\text { overfeeding ( } 130 \% \text { of total energy } \\
\text { expenditure) or underfeeding }(70 \%) \text {, } \\
\text { separated by eucaloric }(100 \%) \\
\text { washout period. Total energy } \\
\text { expenditure and leptin levels were } \\
\text { measured during the third day of } \\
\text { each treatment. }\end{array}$ & $\begin{array}{l}\text { Leptin levels were acutely } \\
\text { responsive to negative energy } \\
\text { balance, but not to positive energy } \\
\text { balance unless subjects were } \\
\text { previously underfed. During } \\
\text { overfeeding, leptin levels increased } \\
\text { by } 25 \pm 11 \% \text { when subjects were } \\
\text { underfed first, but did not increase } \\
\text { when subjects were overfed first. }\end{array}$ & $20-35$ & 0 & 8 & 0 \\
\hline $\begin{array}{c}\text { Effect of weight gain on } \\
\text { cardiac autonomic control } \\
\text { during wakefulness and } \\
\text { sleep [72]. }\end{array}$ & $\begin{array}{l}\text { To investigate the effect of fat } \\
\text { gain on cardiac autonomic } \\
\text { control during wakefulness } \\
\text { and sleep in humans. }\end{array}$ & $\begin{array}{l}\text { Non-obese subjects were engaged in } \\
\text { either a gaining-weight diet ( } 4 \mathrm{~kg} \text { in } \\
8 \text { weeks) followed by an } 8 \text {-week } \\
\text { weight-loss period or a } \\
\text { weight-maintainer control. Analysis } \\
\text { of heart rate variability was } \\
\text { performed at baseline, after weight } \\
\text { gain, and after weight loss, to } \\
\text { examine the relationship between } \\
\text { changes in heart rate variability and } \\
\text { changes in insulin, leptin, and } \\
\text { adiponectin levels. }\end{array}$ & $\begin{array}{l}\text { Weight gain was associated with } \\
\text { increased insulin and leptin } \\
\text { concentrations. Insulin, leptin, and } \\
\text { adiponectin increased after fat gain } \\
\text { and fell after fat loss. }\end{array}$ & $26-32$ & 38 & & 36 \\
\hline
\end{tabular}


Table 2. Cont.

\begin{tabular}{|c|c|c|c|c|c|c|c|}
\hline $\begin{array}{l}\text { Randomized and } \\
\text { Quasi-Randomized } \\
\text { Controlled Trials }\end{array}$ & Aim & Methods & Main Outcomes & Age Range & Fem $(\%)$ & BMI > 25 & BMI $<25$ \\
\hline $\begin{array}{l}\text { The fall in leptin } \\
\text { concentration is a major } \\
\text { determinant of the metabolic } \\
\text { adaptation induced by } \\
\text { caloric restriction, } \\
\text { independently of the } \\
\text { changes in leptin circadian } \\
\text { rhythms [73]. }\end{array}$ & $\begin{array}{l}\text { To explore the changes in } 24-\mathrm{h} \\
\text { leptin circadian rhythms in } \\
\text { response to caloric restriction, } \\
\text { and the relationship between } \\
\text { these changes and metabolic } \\
\text { adaptation. }\end{array}$ & $\begin{array}{l}\text { Obese subjects were assigned to a } \\
\text { control group or a caloric restriction } \\
\text { group for } 6 \text { months. Leptin } \\
\text { concentration was assessed every } \\
30 \text { min for } 24 \mathrm{~h} \text {, and leptin circadian } \\
\text { variations were fitted by Cosinor } \\
\text { analysis. Sedentary energy } \\
\text { expenditure and urinary } \\
\text { catecholamine excretion were } \\
\text { measured for } 24 \mathrm{~h} \text { in a metabolic } \\
\text { chamber. }\end{array}$ & $\begin{array}{l}\text { A decrease in the } 24-h \text { mesor of } \\
\text { circulating leptin of } 44 \pm 3 \% \text { was } \\
\text { observed. The diurnal amplitude of } \\
\text { leptin slightly increased over the } \\
\text { diet. A metabolic adaptation of } \\
-126 \pm 25 \mathrm{kcal} / \mathrm{d} \text { with a decrease in } \\
\text { urinary norepinephrine and T3 } \\
\text { concentrations was observed, } \\
\text { independently of the changes in } \\
\text { mesor leptin. }\end{array}$ & $26-48$ & 57 & 46 & 0 \\
\hline $\begin{array}{l}\text { Improvements in vascular } \\
\text { health by a low-fat diet, but } \\
\text { not a high-fat diet, are } \\
\text { mediated by changes in } \\
\text { adipocyte biology [74]. }\end{array}$ & $\begin{array}{l}\text { To examine how modulations } \\
\text { in flow-mediated dilation by } \\
\text { high-fat and low-fat diets } \\
\text { relate to changes in adipocyte } \\
\text { parameters. }\end{array}$ & $\begin{array}{l}\text { Obese subjects were randomized to } \\
\text { a high-fat diet ( } 60 \% \text { kcal as fat) or a } \\
\text { low-fat diet ( } 25 \% \text { kcal as fat) for } 6 \\
\text { weeks. Both groups were restricted } \\
\text { by } 25 \% \text { of their energy needs. }\end{array}$ & $\begin{array}{l}\text { Bodyweight decreased in both } \\
\text { groups. Fat mass and waist } \\
\text { circumference were reduced in the } \\
\text { low-fat group only }(-4.4 \pm 0.3 \mathrm{~kg} \text {; } \\
\quad-3.6 \pm 0.8 \mathrm{~cm} \text {, respectively). } \\
\text { Increases in plasma adiponectin and } \\
\text { decreases in resistin were shown by } \\
\text { the low-fat diet only. Greater } \\
\text { decreases in leptin were observed } \\
\text { with low-fat }(-48 \pm 9 \%) \text { vs. high-fat } \\
(-28 \pm 12 \%) \text { diets. }\end{array}$ & $32-40$ & 70 & 17 & 0 \\
\hline $\begin{array}{l}\text { Effects of dietary } \\
\text { composition on energy } \\
\text { expenditure during } \\
\text { weight-loss } \\
\text { maintenance [75]. }\end{array}$ & $\begin{array}{l}\text { To examine the effects of three } \\
\text { diets, differing widely in } \\
\text { macronutrient composition } \\
\text { and glycemic load, on energy } \\
\text { expenditure following } \\
\text { weight loss. }\end{array}$ & $\begin{array}{l}\text { Obese subjects, after } 10 \% \text { to } 15 \% \\
\text { weight loss in a diet, consumed an } \\
\text { isocaloric low-fat diet }(60 \% \\
\text { carbohydrate, } 20 \% \text { fat, } 20 \% \text { protein; } \\
\text { high glycemic load), low-glycemic } \\
\text { index diet ( } 40 \% \text { carbohydrate, } 40 \% \\
\text { fat, and } 20 \% \text { protein; moderate } \\
\text { glycemic load), and very } \\
\text { low-carbohydrate diet (10\% } \\
\text { carbohydrate, } 60 \% \text { fat, and } 30 \% \\
\text { protein; low glycemic load) in } \\
\text { random order, for } 4 \text { weeks. }\end{array}$ & $\begin{array}{l}\text { Leptin was highest with the low-fat } \\
\text { diet, intermediate with the } \\
\text { low-glycemic index diet, and lowest } \\
\text { with the } \\
\text { very-low-carbohydrate diet. }\end{array}$ & $24-38$ & 38 & 21 & 0 \\
\hline
\end{tabular}


Table 2. Cont.

\begin{tabular}{|c|c|c|c|c|c|c|c|}
\hline $\begin{array}{l}\text { Randomized and } \\
\text { Quasi-Randomized } \\
\text { Controlled Trials }\end{array}$ & Aim & Methods & Main Outcomes & Age Range & Fem $(\%)$ & BMI > 25 & BMI $<25$ \\
\hline $\begin{array}{c}\text { Whether a } \\
\text { low-glycemic-load } \\
\text { experimental diet was more } \\
\text { satiating than a } \\
\text { high-glycemic-load diet [76]. }\end{array}$ & $\begin{array}{l}\text { To investigate the effect of low } \\
\text { and high glycemic load diets } \\
\text { on satiety and BMI, sex, and } \\
\text { serum leptin. }\end{array}$ & $\begin{array}{l}\text { Non-obese and obese subjects were } \\
\text { crossed in a feeding study, testing } \\
\text { low- vs. high-glycemic-load diets } \\
\text { for } 28 \text { days, with isocaloric } \\
\text { macronutrient distributions } \\
\text { differing only in glycemic load and } \\
\text { fiber. Fasting leptin levels were } \\
\text { measured after each of the } \\
\text { diet periods. }\end{array}$ & $\begin{array}{l}\text { Serum leptin concentrations did not } \\
\text { differ after the two diet treatments. }\end{array}$ & $19-42$ & 50 & 42 & 40 \\
\hline $\begin{array}{l}\text { Alternate day fasting for } \\
\text { weight loss in normal weight } \\
\text { and overweight subjects: a } \\
\text { randomized controlled } \\
\text { trial [77]. }\end{array}$ & $\begin{array}{l}\text { To examine the effect of } \\
\text { alternate-day fasting on body } \\
\text { weight and coronary heart } \\
\text { disease risk in } \\
\text { non-obese subjects. }\end{array}$ & $\begin{array}{l}\text { Obese subjects were randomized to } \\
\text { either an alternate day } \\
\text { fasting-ADF; ad libitum "feed } \\
\text { day", alternated with } 25 \% \text { energy } \\
\text { intake "fast day" - group or a } \\
\text { control group for } 12 \text { weeks. }\end{array}$ & $\begin{array}{l}\text { Bodyweight decreased in the } \\
\text { alternate-day fasting group. } \\
\text { Adiponectin levels increased while } \\
\text { leptin decreased in the intervention } \\
\text { group vs. controls. LDL cholesterol, } \\
\text { HDL cholesterol, homocysteine and } \\
\text { resistin concentrations } \\
\text { remained unchanged. }\end{array}$ & $42-50$ & 73 & 30 & 0 \\
\hline $\begin{array}{l}\text { Effects of experimental sleep } \\
\text { restriction on caloric intake } \\
\text { and activity energy } \\
\text { expenditure [78]. }\end{array}$ & $\begin{array}{l}\text { To determine the effect of } \\
8 \text { days / } 8 \text { nights of sleep } \\
\text { restriction on caloric intake, } \\
\text { activity energy expenditure, } \\
\text { and circulating levels of leptin } \\
\text { and ghrelin. }\end{array}$ & $\begin{array}{l}\text { Obese subjects were randomized } \\
\text { into usual sleep vs. a } 2 / 3 \text { sleep } \\
\text { restriction for } 8 \text { days } / 8 \text { nights in a } \\
\text { hospital-based clinical research unit. } \\
\text { Parameters of caloric intake, activity } \\
\text { energy expenditure, and circulating } \\
\text { levels of leptin and ghrelin } \\
\text { were analyzed. }\end{array}$ & $\begin{array}{l}\text { Caloric intake increased in the } \\
\text { sleep-restricted group and } \\
\text { decreased in the control group. } \\
\text { Sleep restriction was not associated } \\
\text { with changes in activity energy } \\
\text { expenditure. No change was seen in } \\
\text { the levels of leptin or ghrelin. }\end{array}$ & $18-40$ & 35 & 17 & 0 \\
\hline
\end{tabular}


Table 2. Cont.

\begin{tabular}{|c|c|c|c|c|c|c|c|}
\hline $\begin{array}{l}\text { Randomized and } \\
\text { Quasi-Randomized } \\
\text { Controlled Trials }\end{array}$ & Aim & Methods & Main Outcomes & Age Range & Fem $(\%)$ & $\mathrm{BMI}>25$ & BMI $<25$ \\
\hline $\begin{array}{l}\text { Small-sided games training } \\
\text { reduces CRP, IL-6 and leptin } \\
\text { in sedentary, middle-aged } \\
\text { men [79]. }\end{array}$ & $\begin{array}{l}\text { To improve chronic systemic } \\
\text { inflammation, which provides } \\
\text { protection against the ensuing } \\
\text { development of chronic } \\
\text { disease. }\end{array}$ & $\begin{array}{l}\text { Subjects were engaged in cycling or } \\
\text { small-sided games } 3 \text { days/week for } \\
8 \text { weeks, or sedentary control } \\
\text { conditions. Pre- and post- } \\
\text { evaluations included a dual-energy } \\
\text { X-ray absorptiometry scan, } \\
\text { sub-maximal aerobic capacity (VO2) } \\
\text { and fasting blood analyses of } \\
\text { C-reactive protein, interleukin-6, } \\
\text { IL-1 } 1 \beta \text {, tumor necrosis factor- } \alpha \text {, and } \\
\text { leptin; IL-10, IL- } 1 \text { receptor agonist, } \\
\text { and adiponectin. }\end{array}$ & $\begin{array}{l}\text { Both treatments increased } \\
\text { submaximal VO2 and decreased } \\
\text { total body fat mass and C-reactive } \\
\text { protein. Only small-sided games } \\
\text { increased total body fat-free mass } \\
\text { and the concentration of plasma } \\
\text { IL-6 and leptin. }\end{array}$ & $40-58$ & 0 & 32 & 0 \\
\hline $\begin{array}{c}\text { Differential effects of leptin } \\
\text { on adiponectin expression } \\
\text { with weight gain, versus } \\
\text { obesity [80]. }\end{array}$ & $\begin{array}{l}\text { To investigate the role of } \\
\text { weight gain, and the } \\
\text { consequent changes in leptin, } \\
\text { on altering adiponectin } \\
\text { expression in humans. }\end{array}$ & $\begin{array}{c}\text { Non-obese subjects were engaged to } \\
\text { either gain } 5 \% \text { of body weight by } \\
8 \text { weeks of overfeeding or to } \\
\text { maintain weight. }\end{array}$ & $\begin{array}{l}\text { Modest weight gain }(3.8 \pm 1.2 \mathrm{~kg}) \text {, } \\
\text { but not weight maintenance, } \\
\text { resulted in an increased adiponectin } \\
\text { level, positively correlated with } \\
\text { changes in leptin. In vitro analyses } \\
\text { showed that leptin activates cellular } \\
\text { signaling pathways and increases } \\
\text { adiponectin mRNA in } \\
\text { normal-weight, but not in obese, } \\
\text { adipose tissue. Obese subjects } \\
\text { showed increased caveolin-1 } \\
\text { expression, which attenuates } \\
\text { leptin-dependent increases } \\
\text { in adiponectin. }\end{array}$ & $22-35$ & 14 & 0 & 44 \\
\hline
\end{tabular}


Table 2. Cont.

\begin{tabular}{|c|c|c|c|c|c|c|c|}
\hline $\begin{array}{l}\text { Randomized and } \\
\text { Quasi-Randomized } \\
\text { Controlled Trials }\end{array}$ & Aim & Methods & Main Outcomes & Age Range & Fem $(\%)$ & BMI > 25 & BMI $<25$ \\
\hline $\begin{array}{l}\text { Randomized trial testing the } \\
\text { effects of eating frequency } \\
\text { on two hormonal } \\
\text { biomarkers of metabolism } \\
\text { and energy balance [81]. }\end{array}$ & $\begin{array}{l}\text { To verify the possible } \\
\text { influence of eating frequency } \\
\text { on fasting plasma insulin-like } \\
\text { growth factor-I and leptin. }\end{array}$ & $\begin{array}{l}\text { The effects of eating frequency on } \\
\text { fasting plasma insulin-like growth } \\
\text { factor-I (IGF-1) and leptin were } \\
\text { observed in non-obese subjects } \\
\text { engaged in two eucaloric } \\
\text { interventions lasting } 21 \text { days each: } \\
\text { low frequency ( } 3 \text { eating } \\
\text { occasions/day) and high frequency } \\
\text { (8 eating occasions/day). }\end{array}$ & $\begin{array}{c}\text { There were lower serum IGF-1 } \\
\text { levels when subjects underwent } \\
\text { high- compared to } \\
\text { low-eating-frequency conditions. } \\
\text { There was no association between } \\
\text { eating frequency and plasma } \\
\text { leptin levels. }\end{array}$ & $19-38$ & 73 & & 11 \\
\hline $\begin{array}{l}\text { Thyroid hormones and } \\
\text { changes in body weight and } \\
\text { metabolic parameters in } \\
\text { response to weight-loss diets: } \\
\text { the "Pounds Lost" trial [82]. }\end{array}$ & $\begin{array}{l}\text { To examine the associations } \\
\text { between thyroid hormones } \\
\text { and changes in body weight } \\
\text { and resting metabolic rate } \\
\text { (RMR) in a diet-induced } \\
\text { weight-loss setting. }\end{array}$ & $\begin{array}{l}\text { Obese subjects from the 2-year } \\
\text { "Pounds Lost" trial were assessed } \\
\text { for body weight and resting } \\
\text { metabolic parameters. Thyroid } \\
\text { hormones (free triiodothyronine } \\
\text { (T3), free thyroxine (T4), total T3, } \\
\text { total T4, and thyroid-stimulating } \\
\text { hormone (TSH)), anthropometric } \\
\text { measurements, and biochemical } \\
\text { parameters were assessed at } \\
\text { baseline, } 6 \text { months, and } 24 \text { months. }\end{array}$ & $\begin{array}{l}\text { Decreases in free T3 and total T3 } \\
\text { levels were positively associated } \\
\text { with changes in body weight and } \\
\text { leptin, GLU, insulin, and } \\
\text { triglycerides, both in } 6 \text { months and } \\
2 \text { years. No association was } \\
\text { observed between baseline leptin } \\
\text { levels and weight change. }\end{array}$ & $30-70$ & 83 & 569 & 0 \\
\hline $\begin{array}{l}\text { Diurnal distribution of } \\
\text { carbohydrates and fat affects } \\
\text { substrate oxidation and } \\
\text { adipokine secretion in } \\
\text { humans [83]. }\end{array}$ & $\begin{array}{l}\text { To investigate the effects of } \\
\text { dietary patterns on energy } \\
\text { metabolism, and circulating } \\
\text { lipids, adipokines, and } \\
\text { inflammatory markers. }\end{array}$ & $\begin{array}{l}\text { Non-obese subjects underwent two } \\
\text { isocaloric 4-week diets: } \\
\text { (1) carbohydrate-rich meals until } \\
\text { 13:30 and fat-rich meals between } \\
\text { 16:30 and 22:00; or (2) the inverse } \\
\text { sequence of meals. During a 12-h } \\
\text { clinical investigation day after each } \\
\text { intervention period, two meal } \\
\text { tolerance tests were performed, at } \\
\text { 09:00 and 15:40, respectively. } \\
\text { Substrate oxidation and circulating } \\
\text { lipids, adipokines, and cytokines } \\
\text { were assessed pre- and } \\
\text { postprandially. }\end{array}$ & $\begin{array}{l}\text { Diurnal patterns of triglycerides, } \\
\text { LDL cholesterol, leptin, visfatin, and } \\
\text { LPS-induced cytokine secretion in } \\
\text { blood leukocytes were modulated } \\
\text { by the diets. Average daily } \\
\text { concentrations of leptin and visfatin } \\
\text { were lower on Diet } 2 \text { than on Diet } 1 .\end{array}$ & $42-48$ & 0 & & 29 \\
\hline
\end{tabular}


Table 2. Cont.

\begin{tabular}{|c|c|c|c|c|c|c|c|}
\hline $\begin{array}{l}\text { Randomized and } \\
\text { Quasi-Randomized } \\
\text { Controlled Trials }\end{array}$ & Aim & Methods & Main Outcomes & Age Range & Fem $(\%)$ & BMI $>25$ & BMI $<25$ \\
\hline $\begin{array}{l}\text { Effects of alternate-day } \\
\text { fasting or daily calorie } \\
\text { restriction on body } \\
\text { composition, fat distribution, } \\
\text { and circulating adipokines: } \\
\text { secondary analysis of a } \\
\text { randomized controlled } \\
\text { trial [84]. }\end{array}$ & $\begin{array}{l}\text { To compare changes in the } \\
\text { visceral adipose } \\
\text { tissue:saturated adipose tissue } \\
\text { ratio, fat-free mass:total mass } \\
\text { ratio, and the adipokine profile } \\
\text { between alternate-day fasting } \\
\text { and daily calorie restriction. }\end{array}$ & $\begin{array}{l}\text { Obese subjects were signed to (1) } \\
\text { alternate-day fasting (alternating } \\
\text { every } 24 \text { h between consuming } 25 \% \\
\text { or } 125 \% \text { of energy needs); (2) calorie } \\
\text { restriction (consuming } 75 \% \text { of needs } \\
\text { every day); or (3) control } \\
\text { (consuming } 100 \% \text { of needs every } \\
\text { day) over } 24 \text { weeks. }\end{array}$ & $\begin{array}{l}\text { Visceral adipose } \\
\text { tissue:subcutaneous adipose tissue } \\
\text { ratio did not change. The FFM:total } \\
\text { mass ratio similarly increased in } \\
\text { both groups compared to the } \\
\text { control group. Circulating leptin } \\
\text { levels decreased by } 18 \% \text { and } 31 \% \text {, } \\
\text { respectively, in the diet groups } \\
\text { relative to control. The levels of } \\
\text { adiponectin, resistin, IL-6, and } \\
\text { TNF-a did not change in either } \\
\text { intervention group relative to } \\
\text { control. }\end{array}$ & $42-48$ & 84 & 79 & 0 \\
\hline $\begin{array}{l}\text { Six weeks of calorie } \\
\text { restriction improved body } \\
\text { composition and lipid profile } \\
\text { in obese and overweight } \\
\text { former athletes [85]. }\end{array}$ & $\begin{array}{l}\text { To compare the impact of } 20 \% \\
\text { vs. } 30 \% \text { (of total daily energy } \\
\text { expenditure) reduction of } \\
\text { daily caloric intake over } 6 \\
\text { weeks on body mass reduction } \\
\text { and insulin metabolism in } \\
\text { former athletes. }\end{array}$ & $\begin{array}{c}\text { Obese subjects signed to 6-week of } \\
\text { either a } 20 \% \text { or a } 30 \% \text { restriction diet } \\
\text { had body composition variables, } \\
\text { lipid profile (total lipids-TL; total } \\
\text { cholesterol-TCh; HDL } \\
\text { cholesterol-HDL; LDL } \\
\text { cholesterol-LDL; } \\
\text { triglycerides-TG), GLU, insulin, } \\
\text { IGF-1, leptin and adiponectin. }\end{array}$ & $\begin{array}{l}\text { A decrease in TG, TL and leptin, and } \\
\text { an increase in adiponectin levels, } \\
\text { were observed in both diet groups. }\end{array}$ & $29-41$ & 0 & 63 & 0 \\
\hline
\end{tabular}

OGTT, oral glucose tolerance test; HGL, high-density lipoprotein; LDL, low-density lipoprotein. 


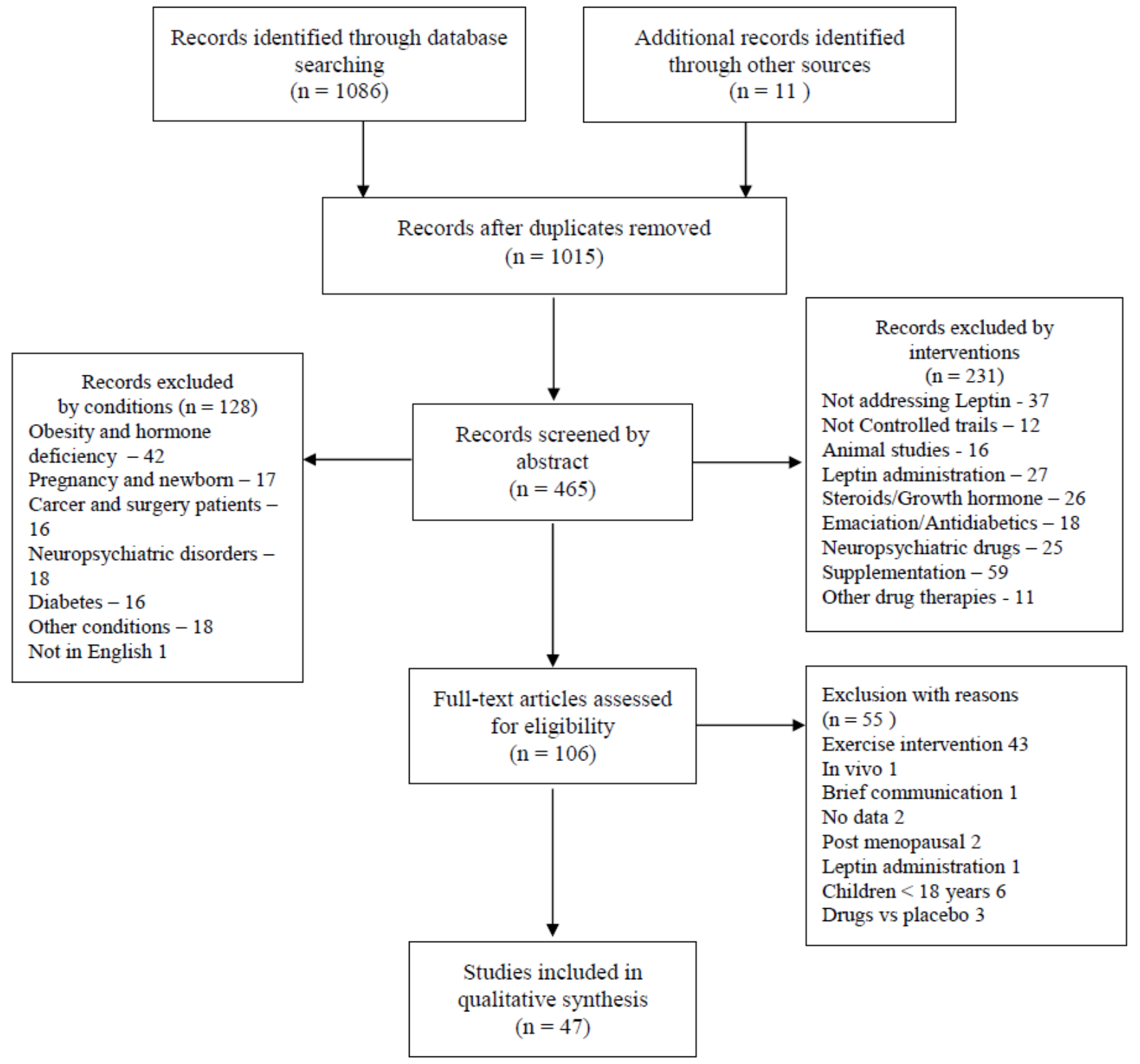

Figure 1. PRISMA search flow.

\section{Results}

The study by Vgontzas et al. [39] showed that in men with obesity, those with sleep apnea have higher leptin levels than those without apnea. Guerci et al. [40] demonstrated that levels of leptin are not influenced by fat intake and that women display higher levels of plasma leptin, regardless of their body weight.

Comparing the effects of diet and exercise on leptin levels in men with obesity undergoing a weight loss regime, Thong et al. [61] observed that leptin levels only decreased in those who either lost weight or changed their body composition. Furthermore, changes in leptin levels correlate with changes in total, subcutaneous, and visceral adipose tissue. Next, by comparing eucaloric and hipper vs. hypo-energetic diets in subjects without obesity, Chin-Chance et al. [62] reported that leptin levels are associated with ad libitum feeding. They showed that hypo-energetic diets decrease leptin levels, while hyper-energetic diets increase leptin levels. It was also found that leptin levels do not immediately return to their previous concentrations when individuals return to a eucaloric diet. Similarly, a study by 
Assali et al. [41] described an 18\% decrease in leptin levels, coupled with insulin resistance and triglycerides, in subjects with obesity during an isoenergetic washout period between two hypo-energetic diets.

In a study by Herrmann et al. [63], subjects not suffering from obesity on diets of different fat and glycemic profiles showed no differences in their basal leptin levels and no effects of OGTT on their leptin responses. In a study by Tsai et al. [42], women without obesity who were either on a diet or exercise regime had similar changes in their leptin levels: a $27 \%$ and $32 \%$ fall after diet and exercise, respectively, that recovered with energy repletion. By performing postprandial thermogenesis tests using different meal configurations in women with and without obesity, Tentolouris et al. [43] observed that fasting energy expenditure correlated with leptin levels.

Matsumoto et al. [44] monitored heart rate variability in women with and without obesity, to analyze leptin interactions with the autonomic nervous system. Reduced sympathetic responsiveness to leptin variations suggested that peripheral leptin resistance was present in women with obesity. Kassab et al. [45] checked daytime leptin levels in women without obesity during Ramadan and found that prolonged fasting with interrupted nocturnal eating was associated with the elevation of both leptin and insulin levels.

When measuring arterial versus venous concentrations of leptin, Eikelis et al. [46] showed that leptin levels are higher in men with obesity and that the brain contributes over $40 \%$ of the whole-body leptin release. Baratta et al. [47] revealed that plasma adiponectin, but not leptin, was correlated with insulin sensitivity and triglycerides in individuals undergoing a long-term weight-loss program. They identified an increase in plasma adiponectin and a decrease in plasma leptin after the program. Weigle et al. [48] analyzed metabolic and appetite parameters in individuals with obesity who were following isoenergetic diets with different protein/fat profiles and concluded that spontaneous energy intake and mesor leptin levels decreased with an ad libitum high-protein diet, despite an increase in ghrelin levels.

Analyzing coronary blood flow in individuals without obesity by ergospirometry and echocardiography, Kiviniemi et al. [49] observed that leptin levels correlated with waist-to-hip ratio, fat percentage, body mass index, LDL cholesterol, oxidized LDL, and apolipoprotein B. Moreover, subjects with subcutaneous adipose tissue had a stronger association with leptin concentrations than those with visceral adipose tissue. The molecular analyses conducted by Joosen et al. [50] revealed that changes in the expression levels of peroxisome proliferator-activated receptor $\gamma 1$ and 2 , and the aP2 transcriptional factor, were positively related to changes in plasma leptin in women without obesity who received a 50\% increase in energy intake for two weeks. Poppitt et al. [64] found that in men without obesity, fatty meals had no effect on postprandial levels of ghrelin; however, they found no decrease in leptin levels. Neither ghrelin nor leptin was correlated with circulating insulin levels.

In a study by Chapelot et al. [51], men without obesity who subtracted a meal from their standard regimen showed an increase in body fat mass and leptin levels, while those who added a meal showed no effect. In Bray et al. [65], men with obesity who were fed fastfood, organic, and meat-based meals had an increase in ghrelin levels only after fast-food ingestion. No changes were reported for leptin levels over a six-hour postprandial period. Carlson et al. [66] reported that fasting levels of insulin, leptin, ghrelin, adiponectin, resistin, and BDNF were not affected by feeding frequency, comparing one and three meals per day for two months. In Abete et al. [67], individuals with obesity who underwent a two-month fish-based hypo-energetic diet had a decrease in leptin levels that was positively correlated with decreased insulin.

Bouhlel et al. [52] investigated the effect of a four-week Ramadan period (fasting from 5 a.m. to 6 p.m.) on leptin levels in men without obesity. Ramadan fasting provoked a reduction in body mass and body fat mass, with no changes being recorded in leptin or adiponectin levels. 
Individuals with obesity on two different sleep regimes over two weeks, in a study by Nedeltcheva et al. [68], showed no difference between leptin and ghrelin levels. Leptin concentrations increased in a similar fashion at the end of each shorter or longer sleep regime. Bortolotti et al. [69] demonstrated that either hypercaloric high-fat or hypercaloric high-fat high-protein diets increased plasma leptin concentrations in men without obesity. In research conducted by Ratliff et al. [70], men with obesity on a low-carb diet who received additional dietary cholesterol showed reductions in fasting insulin and leptin levels that correlated with reductions in body fat mass.

In a study by J. A. Cooper et al. [71], men with obesity undergoing a three-day eucaloric overfeeding or underfeeding diet showed a decrease in the levels of leptin during the underfeeding diet. Leptin levels increased during overfeeding only when individuals were first underfed.

In another study by Bhutani et al. [53], individuals with obesity, enrolled in an alternate-day fasting controlled feeding regimen versus alternate-day fasting self-selected feeding, showed a reduction of $21 \%$ and $23 \%$ in leptin and resistin levels, respectively. Lower triacylglycerol levels were associated with increased adiponectin and reduced leptin levels. In research conducted by Bergouignan et al. [54], after two months of sedentary vs. exercise regimes, women without obesity showed no difference in leptin levels. Their fasting leptin levels were negatively correlated with their spontaneous feeding. Wu et al. [55] analyzed adiponectin, leptin, and bone turnover markers in a large sample of women without obesity and revealed that adiponectin and leptin were the main peptides secreted by adipose tissue.

Individuals not suffering from obesity who committed to an 8-week weight gain followed by an 8-week weight loss regimen for a study by Adachi et al. [72] showed that weight gain is associated with increases in insulin and leptin concentrations. Moreover, immediate weight loss decreased their levels of insulin, leptin, and adiponectin toward baseline values. According to Lecoultre et al. [73], individuals with obesity showed a $44 \%$ decrease in the mesor leptin curve after six months of caloric restriction, although the diurnal amplitude of the curve slightly increased over that period.

Individuals with obesity undergoing both a high-fat (60\% kcal) and a low-fat ( $25 \% \mathrm{kcal})$ diet with $25 \%$ energy restriction for a study by Varady et al. [74] showed decreases in leptin levels (low-fat, $48 \%$ vs. high-fat, $28 \%$ ) and body weight after 6 weeks. Decreases in body fat mass, as well as increases in plasma adiponectin levels, were noted only for the low-fat diet. Benedict et al. [56] showed that in men without obesity under regular sleep vs. sleep deprivation conditions, metabolic turnover demonstrated a pronounced diurnal rhythm, peaking during the early afternoon, in contrast to leptin profiles that peaked early in the night.

Subjects with obesity who were already in the course of weight loss (10-15\%) enrolled in either an isocaloric low-fat high-glycemic, a moderate-fat low-glycemic, or a high-fat very-low-glycemic diet for the study by Ebbeling et al. [75]. This revealed that serum leptin was highest with the low-fat diet, intermediate with the low-glycemic diet, and lowest with the very low-carbohydrate diet.

In the study by Chang et al. [76], individuals with and without obesity undergoing 4 weeks either on an isocaloric low- or a high-glycemic diet showed no difference in their leptin levels afterward. In another study by Varady et al. [77], individuals with obesity who submitted to a three-month alternate daily fasting regimen showed a decrease in their body weight and leptin with an increase in adiponectin levels. Cooper et al. [57] found that subjects with obesity who were undergoing a one-year weight loss regimen with diet and exercise reported decreases in aldosterone levels associated with decreases in leptin and insulin, and with increases in adiponectin levels.

Calvin et al. [78] demonstrated that sleep restriction increased caloric intake in individuals with obesity. Sleep restriction was not associated with changes in energy expenditure, leptin or ghrelin levels. Dos Santos Moraes et al. [58] observed a negative correlation be- 
tween leptin and adiponectin/leptin ratios, which increased and decreased in individuals with obesity, according to the degree of obesity.

Müller et al. [59] reported that men without obesity, submitting to overfeeding followed by a caloric restriction diet and then refeeding, showed a reduction in fat mass during caloric restriction that increased with energy expenditure, leptin, insulin, adiponectin, T3, and testosterone. In those individuals with obesity in a weight-loss program researched by Williams et al. [60], women had higher basal levels of leptin, adiponectin and ghrelin, and the ratios of leptin to adiponectin and leptin to ghrelin. In women, higher ghrelin concentrations predicted greater weight loss and their higher leptin to ghrelin ratio predicted their weight gain within 6 months.

Singh et al. [80] demonstrated that in subjects without obesity who enrolled in a weight gain program, weight gain but not weight maintenance initiates an increase in adiponectin levels. Changes in adiponectin levels positively correlated with changes in leptin levels. In parallel, an in vitro experiment showed that leptin increases adiponectin production in white preadipocytes, while the leptin antagonist has the opposite effect. Comparing normal and obese tissue suggests that the leptin signaling pathways increase adiponectin expression in normal-weight but not in obese adipose tissue.

Perrigue et al. [81] investigated the effect of eating frequency on metabolic markers in subjects without obesity. Meals/day frequencies were negatively correlated with serum IGF-1 levels, but no associations were found for leptin levels. Individuals with obesity undergoing a two-year weight-loss program for the study by Liu et al. [82] reported that within a six-month to a two-year program, a decrease in free T3 and total T3 was positively associated with changes in their body weight, leptin, GLU, insulin, and triglyceride levels. Kessler et al. [83] explored the effects of two daily profiles of isocaloric diets in men without obesity on their metabolic factors. They reported that the diurnal patterns of adipokines were modulated by dietary patterns. Mesor leptin was lower when a carbohydrate-rich meal was consumed up until 1:30 p.m., with fat-rich meals between 4:30 p.m. and 10:00 p.m.

In the study by Trepanowski et al. [84], individuals with obesity who committed to a five-month period of either alternate-day fasting or caloric restriction showed no difference in their ratios of visceral to subcutaneous fat, their total mass ratios similarly increased in both diets, and their leptin levels decreased by $18 \%$ and $31 \%$, respectively. In a study conducted by Hołowko et al. [85], men not suffering from obesity who enrolled in a sixweek $20 \%$ or $30 \%$ hypo-energetic diet showed decreases in leptin levels, triglycerides and total lipids, with an increase in adiponectin levels.

\section{Discussion}

The participation of metabolites that are largely expressed in peripheral tissue such as cytokines (i.e., peroxisome proliferator-activated receptor $\gamma$ co-activator $1 \alpha-\mathrm{PGC}-1 \alpha$, brain-derived neurotrophic factor (BDNF), and irisin) as active players in the etiology of neuropsychiatric diseases has highlighted metabolism as a relevant factor in research on mental health. It is now recognized that our everyday exercise and nutrition choices have long-term consequences on our brain function [86-89].

The identification of the central actions of leptin when signaling through its specific LepRls in the neurons of the neuroendocrine and hippocampal circuits elucidates a complex and integrated central control of body energy (expenditure vs. storage) and sophisticated self-defense of the brain, thus shedding light on how it modulates satiety and compulsion [30].

Evidence suggests that leptin and adiponectin are the major peptides secreted by adipose tissue, and that circulating levels of leptin positively correlate with body fat mass, particularly with subcutaneous adipose tissue. Leptin levels also correlate with the waistto-hip ratio and BMI $[44,49,54,55]$. Leptin levels are higher in individuals with obesity compared to those without obesity [46], as well as in women compared to men [40].

Studies also confirm that leptin levels do not alter under fasting and/or postprandial conditions $[43,64,65]$, whereas the mean levels of leptin seem to respond rapidly to changes 
in caloric intake (diet), both quantitatively and qualitatively. Specifically, leptin levels are more responsive to a negative energy balance regime, meaning that leptin secretion is more likely to decrease under hypocaloric diet conditions than to increase under hypercaloric diet conditions. Moreover, the levels of leptin appear to rapidly return to the standard starting point once eucaloric conditions are restored [53,59,61,70-72,75].

It is suggested that changes in leptin are independent of circadian rhythms and stress factors; however, the endogenous modulation of leptin might be essential in preventing various chronic metabolic and brain diseases $[56,73,75,78,81]$. Therefore, it is necessary to understand the physiology of leptin and a healthy metabolism. Changes in circulating leptin might be selectively responsive to fat stores as a source of energy nutrition, as opposed to glycemic indexes (commonly associated with satiety) that in turn have no impact on leptin secretion $[63,75,76]$. Furthermore, high-fat hypercaloric diets increase leptin levels independently of protein content [69]. Conversely, high-fat hypocaloric diets induce smaller decreases in leptin levels than low-fat diets [74].

From a behavioral perspective, however, Thackray et al. [90] found that high-fat hyperenergetic diets increase leptin levels and the appetite preference for high-fat over low-fat foods, despite reductions in ghrelin levels. Similarly, leptin levels decrease with spontaneous feeding under high-protein diet conditions, independently of increases in ghrelin levels $[48,60,62]$. This suggests that despite the stable feature of leptin, basal leptin levels might be responsive to short-term and long-term alterations in nutrition.

Both hypercaloric and hypocaloric diets modulate leptin levels in accordance with their fat content. While high-fat diets increase leptin levels and result in an increased appetite for high-fat foods, high-protein diets affect the appetite and feeding behaviors in such a manner that they downregulate leptin levels, due to reduced spontaneous feeding. This implies that the feeding control of body fat mass and obesity is ultimately linked to the downregulation and stabilization of leptin production.

Although leptin levels are not correlated with sleeping/waking regimes [56,68,78], sleep disorders related to obesity, such as sleep apnea, appear to be associated with increases in leptin levels [39]. Furthermore, diurnal leptin concentrations are affected by the time of day, regarding diet [51]. For instance, mesor leptin is lower when carbohydrate-rich meals are consumed before 1:30 p.m. and fat-rich meals are consumed between 4:30 p.m. and 10 p.m. [83].

In addition, adiponectin, known for its role in attenuating inflammation and regulating GLU levels and fatty acid breakdown, is also elevated in individuals with obesity [53,72,74,77,91,92]; it seems to have a positive metabolic counteraction against obesity and metabolic disorders. In line with this finding, subjects with obesity in a study by Dos Santos Moraes et al. [58] showed higher or lower concentrations of leptin/adiponectin according to their leptin levels and the degree of obesity. Later, Singh et al. [80] demonstrated that leptin activates the cellular signaling pathways that increase adiponectin expression in the adipose tissue of individuals without obesity.

These findings show that leptin levels seem to reflect inflammatory states in obesity, and that a reduction in leptin levels improves GLU metabolism, an effect that is more prominent in those who are overweight and obese $[41,45,57,59,67,70,72,82]$. This interplay of inflammatory cytokines in the control of body weight/composition makes leptin a pro-homeostasis stabilizer factor and might explain why it has not been successfully manipulated pharmacologically $[93,94]$.

The involvement of central circuits in the expression of LepRls sheds light on the integration of metabolism as a contributing factor for feeding and stress-related neuropsychiatric disorders [95-98]. The function of leptin in the CNS requires fine-tuning of LepRls signaling throughout the neuroendocrine axes, which is a coadjutant in the physiopathology of these disorders. For instance, leptin suppresses the secretion of cortisol during the stress activation of the adrenal axis, thus contributing to the inhibition of chronic overactivation of the hypothalamic-pituitary-adrenal axis, whereas lowered leptin levels are associated with an increased risk of developing dementia [28]. Reduction in the energetic 
reserves and leptin production appear to cause a compensatory change in the reward system and the secretion of orexigenic and anorexigenic neuropeptides [99,100]; meanwhile, negative feedback in the expression of LepR1 as a response to high leptin concentrations has been suggested to occur as a state of leptin resistance and to result in an inability to detect satiety [86].

\section{Final Considerations}

Leptin secretion is more prone to be downregulated by the rate of energy intake, and diet can modulate leptin levels, both quantitatively and qualitatively. The stabilization of circulating leptin at high levels has long-term implications for weight levels and the feeding reward system, the stress-activation response, and the potential development of neuropsychiatric disorders of behavior.

Author Contributions: G.G.d.A.: conceptualization, data search and analysis, writing-original draft preparation, E.M.-C.: writing-original draft preparation. All authors have read and agreed to the published version of the manuscript.

Funding: This research received no external funding. It was funded only by an internal grant from the University School of Physical Education. Project No. 503 62/05 “Effectiveness of various therapeutic forms and their influence on nervous, muscular and vascular plasticity in patients after ischemic stroke".

Conflicts of Interest: The author declares no competing interest.

\section{References}

1. Freed, C. Psychic factors in the development and treatment of obesity. J. Am. Med. Assoc. 1947, 133, 369-373. [CrossRef]

2. Bouchard, C. Gene-environment interactions in the etiology of obesity: Defining the fundamentals. Obesity 2008, 16, 5-10. [CrossRef]

3. Chung, W.K.; Leibel, R.L. Considerations regarding the genetics of obesity. Obesity 2008, 16, 33-39. [CrossRef]

4. Hinney, A.; Hebebrand, J. Polygenic obesity in humans. Obes. Facts 2008, 1, 35-42. [CrossRef]

5. Kleinendorst, L.; van Haelst, M.M.; van den Akker, E.L.T. Genetics of Obesity. Exp. Suppl. 2019, 111, 419-441. [CrossRef]

6. Shuldiner, A.R. Obesity genes and gene-environment-behavior interactions: Recommendations for a way forward. Obesity 2008, 16, 79-81. [CrossRef]

7. Wareham, N.J.; Young, E.H.; Loos, R.J.F. Epidemiological study designs to investigate gene-behavior interactions in the context of human obesity. Obesity 2008, 16, 66-71. [CrossRef]

8. Leibel, R.L. Energy In, Energy Out, and the Effects of Obesity-Related Genes. N. Engl. J. Med. 2008, 359, 2603-2604. [CrossRef]

9. Warden, C.H.; Fisler, J.S. Gene-nutrient and gene-physical activity summary-genetics viewpoint. Obesity 2008, 16, 55-59. [CrossRef]

10. Capers, P.L.; Fobian, A.D.; Kaiser, K.A.; Borah, R.; Allison, D.B. A systemic review and meta-analysis of randomized controlled trials of the impact of sleep duration on adiposity and components of energy balance. Obes. Rev. 2015, 16, 771-782. [CrossRef] [PubMed]

11. Considine, R.V. Leptin and obesity in humans. Eat. Weight. Disord. Stud. Anorex. Bulim. Obes. 1997, 2, 61-66. [CrossRef]

12. Friedman, J.M.; Leibel, R.L.; Siegel, D.S.; Walsh, J.; Bahary, N. Molecular mapping of the mouse ob mutation. Genomics 1991, 11, 1054-1062. [CrossRef]

13. St-Onge, M.P. The Role of Sleep Duration in the Regulation of Energy balance: Effects on Energy intakes and Expenditure. J. Clin. Sleep Med. 2013, 9, 73-80. [CrossRef]

14. Harter, C.J.L.; Kavanagh, G.S.; Smith, J.T. The role of kisspeptin neurons in reproduction and metabolism. J. Endocrinol. 2018, 238, 173-183. [CrossRef] [PubMed]

15. La Cava, A. Leptin in inflammation and autoimmunity. Cytokine 2017, 98, 51-58. [CrossRef] [PubMed]

16. Mishra, S.; Harris, T.B.; Hsueh, W.C.; Hue, T.; Leak, T.S.; Li, R.; Mehta, M.; Vaisse, C.; Sahyoun, N.R. The association of serum leptin with mortality in older adults. PLoS ONE 2015, 10, e0140763. [CrossRef]

17. Catteau, A.; Caillon, H.; Barrière, P.; Denis, M.G.; Masson, D.; Fréour, T. Leptin and its potential interest in assisted reproduction cycles. Hum. Reprod. Update 2016, 22, 320-341. [CrossRef]

18. Chou, S.H.; Mantzoros, C. Role of leptin in human reproductive disorders. J. Endocrinol. 2014, 223, T49-T62. [CrossRef]

19. He, S.; Le, N.A.; Ramirez-Zea, M.; Martorell, R.; Narayan, K.M.V.; Stein, A.D. Leptin partially mediates the association between early-life nutritional supplementation and long-term glycemic status among women in a Guatemalan longitudinal cohort. Am. J. Clin. Nutr. 2020, 111, 804-813. [CrossRef] [PubMed] 
20. Wauters, M.; Considine, R.; Löfgren, A.; Van Broeckhoven, C.; Van der Auwera, J.C.; De Leeuw, I.; Van Gaal, L. Associations of leptin with body fat distribution and metabolic parameters in non-insulin-dependent diabetic patients: No effect of apolipoprotein E polymorphism. Metab. Clin. Exp. 2000, 49, 724-730. [CrossRef]

21. Da Silva, A.A.; do Carmo, J.M.; Hall, J.E. CNS Regulation of Glucose Homeostasis: Role of the Leptin-Melanocortin System. Curr. Diabetes Rep. 2020, 20, 29. [CrossRef]

22. Fernández-Formoso, G.; Pérez-Sieira, S.; González-Touceda, D.; Dieguez, C.; Tovar, S. Leptin, 20 years of searching for glucose homeostasis. Life Sci. 2015, 140, 4-9. [CrossRef] [PubMed]

23. Tartaglia, L.A. The leptin receptor. J. Biol. Chem. 1997, 272, 6093-6096. [CrossRef] [PubMed]

24. Caldeira, R.S.; Panissa VL, G.; Inoue, D.S.; Campos, E.Z.; Monteiro, P.A.; Giglio, B.d.M.; Pimentel, G.D.; Hofmann, P.; Lira, F.S. Impact to short-term high intensity intermittent training on different storages of body fat, leptin and soluble leptin receptor levels in physically active non-obese men: A pilot investigation. Clin. Nutr. ESPEN 2018, 28, 186-192. [CrossRef] [PubMed]

25. Boutari, C.; Pappas, P.D.; Mintziori, G.; Nigdelis, M.P.; Athanasiadis, L.; Goulis, D.G.; Mantzoros, C.S. The effect of underweight on female and male reproduction. Metab. Clin. Exp. 2020, 107, 154-229. [CrossRef] [PubMed]

26. Marazziti, D.; Rutigliano, G.; Baroni, S.; Landi, P.; Dell'Osso, L. Metabolic syndrome and major depression. CNS Spectrums. 2014, 19, 293-304. [CrossRef] [PubMed]

27. Mintziori, G.; Nigdelis, M.P.; Mathew, H.; Mousiolis, A.; Goulis, D.G.; Mantzoros, C.S. The effect of excess body fat on female and male reproduction. Metab. Clin. Exp. 2020, 107, 154-193. [CrossRef] [PubMed]

28. Stieg, M.R.; Sievers, C.; Farr, O.; Stalla, G.K.; Mantzoros, C.S. Leptin: A hormone linking activation of neuroendocrine axes with neuropathology. Psychoneuroendocrinology 2015, 51, 47-57. [CrossRef]

29. Ángeles Martínez-García, M.; Moncayo, S.; Insenser, M.; Álvarez-Blasco, F.; Luque-Ramírez, M.; Escobar-Morreale, H.F. Postprandial responses of circulating energy homeostasis mediators to single macronutrient challenges: Influence of obesity and sex hormones. Food Funct. 2021, 12, 1051-1062. [CrossRef] [PubMed]

30. Hamilton, K.; Harvey, J. The neuronal actions of leptin and the implications for treating alzheimer's disease. Pharmaceuticals 2021, 14, 52. [CrossRef]

31. Voigtmann, F.; Wolf, P.; Landgraf, K.; Stein, R.; Kratzsch, J.; Schmitz, S.; Abou Jamra, R.; Blüher, M.; Meiler, J.; Beck-Sickinger, A.G.; et al. Identification of a novel leptin receptor (LEPR) variant and proof of functional relevance directing treatment decisions in patients with morbid obesity. Metab. Clin. Exp. 2021, 116, 154438. [CrossRef]

32. Javor, E.D.; Cochran, E.K.; Musso, C.; Young, J.R.; DePaoli, A.M.; Gorden, P. Long-term efficacy of leptin replacement in patients with generalized lipodystrophy. Diabetes 2005, 54, 1994-2002. [CrossRef] [PubMed]

33. Oral, E.A.; Simha, V.; Ruiz, E.; Andewelt, A.; Premkumar, A.; Snell, P.; Wagner, A.J.; DePaoli, A.M.; Reitman, M.L.; Taylor, S.I.; et al. Leptin-Replacement Therapy for Lipodystrophy. N. Engl. J. Med. 2002, 346, 570-578. [CrossRef] [PubMed]

34. Cao, B.; Chen, Y.; Brietzke, E.; Cha, D.; Shaukat, A.; Pan, Z.; Park, C.; Subramaniapillai, M.; Zuckerman, H.; Grant, K.; et al. Leptin and adiponectin levels in major depressive disorder: A systematic review and meta-analysis. J. Affect. Disord. 2018, 238, 101-110. [CrossRef]

35. Carvalho, A.F.; Rocha, D.Q.C.; McIntyre, R.S.; Mesquita, L.M.; Köhler, C.A.; Hyphantis, T.N.; Sales, P.M.G.; Machado-Vieira, R.; Berk, M. Adipokines as emerging depression biomarkers: A systematic review and meta-analysis. J. Psychiatr. Res. 2014, 59, 28-37. [CrossRef] [PubMed]

36. Chan, J.L.; Heist, K.; DePaoli, A.M.; Veldhuis, J.D.; Mantzoros, C.S. The role of falling leptin levels in the neuroendocrine and metabolic adaptation to short-term starvation in healthy men. J. Clin. Investig. 2003, 111, 1409-1421. [CrossRef]

37. Kiernan, K.; MacIver, N.J. The Role of the Adipokine Leptin in Immune Cell Function in Health and Disease. Front. Immunol. 2021, 11, 3656. [CrossRef] [PubMed]

38. Moher, D.; Liberati, A.; Tetzlaff, J.; Altman, D.G.; Altman, D.; Antes, G.; Atkins, D.; Barbour, V.; Barrowman, N.; Berlin, J.A.; et al. Preferred reporting items for systematic reviews and meta-analyses: The PRISMA statement. PLoS Med. 2009, 6, e1000097. [CrossRef]

39. Vgontzas, A.N.; Papanicolaou, D.A.; Bixler, E.O.; Hopper, K.; Lotsikas, A.; Lin, H.M.; Kales, A.; Chrousos, G.P. Sleep apnea and daytime sleepiness and fatigue: Relation to visceral obesity, insulin resistance, and hypercytokinemia. J. Clin. Endocrinol. Metab. 2000, 85, 1151-1158. [CrossRef]

40. Guerci, B.; Hadjadj, S.; Quilliot, D.; Ziegler, O.; Drouin, P. No acute response of leptin to an oral fat load in obese patients and during circadian rhythm in healthy controls. Eur. J. Endocrinol. 2000, 143, 649-655. [CrossRef]

41. Assali, A.R.; Ganor, A.; Beigel, Y.; Shafer, Z.; Hershcovici, T.; Fainaru, M. Insulin resistance in obesity: Body-weight or energy balance? J. Endocrinol. 2001, 171, 293-298. [CrossRef] [PubMed]

42. Tsai, A.C.; Sandretto, A.; Chung, Y.C. Dieting is more effective in reducing weight but exercise is more effective in reducing fat during the early phase of a weight-reducing program in healthy humans. J. Nutr. Biochem. 2003, 14, 541-549. [CrossRef]

43. Tentolouris, N.; Tsigos, C.; Perea, D.; Koukou, E.; Kyriaki, D.; Kitsou, E.; Daskas, S.; Daifotis, Z.; Makrilakis, K.; Raptis, S.A.; et al. Differential effects of high-fat and high-carbohydrate isoenergetic meals on cardiac autonomic nervous system activity in lean and obese women. Metab. Clin. Exp. 2003, 52, 1426-1432. [CrossRef]

44. Matsumoto, T.; Miyatsuji, A.; Miyawaki, T.; Yanagimoto, Y.; Moritani, T. Potential association between endogenous leptin and sympatho-vagal activities in young obese Japanese women. Am. J. Hum. Biol. 2003, 15, 8-15. [CrossRef] [PubMed] 
45. Kassab, S.E.; Abdul-Ghaffar, T.; Nagalla, D.S.; Sachdeva, U.; Nayar, U. Interactions between leptin, neuropeptide-Y and insulin with chronic diurnal fasting during Ramadan. Ann. Saudi Med. 2004, 24, 345-349. [CrossRef]

46. Eikelis, N.; Lambert, G.; Wiesner, G.; Kaye, D.; Schlaich, M.; Morris, M.; Hastings, J.; Socratous, F.; Esler, M. Extra-adipocyte leptin release in human obesity and its relation to sympathoadrenal function. Am. J. Physiol. Endocrinol. Metab. 2004, 286, E744-E752. [CrossRef]

47. Baratta, R.; Amato, S.; Degano, C.; Farina, M.G.; Patanè, G.; Vigneri, R.; Frittitta, L. Adiponectin relationship with lipid metabolism is independent of body fat mass: Evidence from both cross-sectional and intervention studies. J. Clin. Endocrinol. Metab. 2004, 89, 2665-2671. [CrossRef]

48. Weigle, D.S.; Breen, P.A.; Matthys, C.C.; Callahan, H.S.; Meeuws, K.E.; Burden, V.R.; Purnell, J.Q. A high-protein diet induces sustained reductions in appetite, ad libitum caloric intake, and body weight despite compensatory changes in diurnal plasma leptin and ghrelin concentrations. Am. J. Clin. Nutr. 2005, 82, 41-48. [CrossRef]

49. Kiviniemi, T.O.; Snapir, A.; Saraste, M.; Toikka, J.O.; Raitakari, O.T.; Ahotupa, M.; Hartiala, J.J.; Scheinin, M.; Koskenvuo, J.W. Determinants of coronary flow velocity reserve in healthy young men. Am. J. Physiol. Heart Circ. Physiol. 2006, 291, 564-569. [CrossRef]

50. Joosen, A.M.C.P.; Bakker, A.H.F.; Zorenc, A.H.G.; Kersten, S.; Schrauwen, P.; Westerterp, K.R. PPAR $\gamma$ activity in subcutaneous abdominal fat tissue and fat mass gain during short-term overfeeding. Int. J. Obes. 2006, 30, 302-307. [CrossRef]

51. Chapelot, D.; Marmonier, C.; Aubert, R.; Allègre, C.; Gausseres, N.; Fantino, M.; Louis-Sylvestre, J. Consequence of omitting or adding a meal in man on body composition, food intake, and metabolism. Obesity 2006, 14, 215-227. [CrossRef] [PubMed]

52. Bouhlel, E.; Denguezli, M.; Zaouali, M.; Tabka, Z.; Shephard, R.J. Ramadan fasting's effect on plasma leptin, adiponectin concentrations, and body composition in trained young men. Int. J. Sport Nutr. Exerc. Metab. 2008, 18, 617-627. [CrossRef]

53. Bhutani, S.; Klempel, M.C.; Berger, R.A.; Varady, K.A. Improvements in coronary heart disease risk indicators by alternate-day fasting involve adipose tissue modulations. Obesity 2010, 18, 2152-2159. [CrossRef]

54. Bergouignan, A.; Momken, I.; Schoeller, D.A.; Normand, S.; Zahariev, A.; Lescure, B.; Simon, C.; Blanc, S. Regulation of energy balance during long-term physical inactivity induced by bed rest with and without exercise training. J. Clin. Endocrinol. Metab. 2010, 95, 1045-1053. [CrossRef] [PubMed]

55. Wu, N.; Wang, Q.P.; Li, H.; Wu, X.P.; Sun, Z.Q.; Luo, X.H. Erratum to Relationships between serum adiponectin, leptin concentrations and bone mineral density and bone biochemical markers in Chinese. Clin. Chim. Acta 2010, 411, 1159. [CrossRef]

56. Benedict, C.; Shostak, A.; Lange, T.; Brooks, S.J.; Schiöth, H.B.; Schultes, B.; Born, J.; Oster, H.; Hallschmid, M. Diurnal rhythm of circulating nicotinamide phosphoribosyltransferase (Nampt/visfatin/PBEF): Impact of sleep loss and relation to glucose metabolism. J. Clin. Endocrinol. Metab. 2012, 97, E218-E222. [CrossRef]

57. Cooper, J.N.; Fried, L.; Tepper, P.; Barinas-Mitchell, E.; Conroy, M.B.; Evans, R.W.; Mori Brooks, M.; Woodard, G.A.; Sutton-Tyrrell, $\mathrm{K}$. Changes in serum aldosterone are associated with changes in obesity-related factors in normotensive overweight and obese young adults. Hypertens. Res. 2013, 36, 895-901. [CrossRef]

58. Dos Santos Moraes, A.; Pisani, L.P.; Corgosinho, F.C.; Testa Carvalho, L.O.; Masquio, D.C.L.; Jamar, G.; Sanches, R.B.; Oyama, L.M.; Dâmaso, A.R.; Belote, C.; et al. The role of leptinemia state as a mediator of inflammation in obese adults. Horm. Metab. Res. 2013, 45, 605-610. [CrossRef]

59. Müller, M.J.; Enderle, J.; Pourhassan, M.; Braun, W.; Eggeling, B.; Lagerpusch, M.; Glüer, C.C.; Kehayias, J.J.; Kiosz, D.; BosyWestphal, A. Metabolic adaptation to caloric restriction and subsequent refeeding: The Minnesota Starvation Experiment revisited. Am. J. Clin. Nutr. 2015, 102, 807-819. [CrossRef] [PubMed]

60. Williams, R.L.; Wood, L.G.; Collins, C.E.; Morgan, P.J.; Callister, R. Energy homeostasis and appetite regulating hormones as predictors of weight loss in men and women. Appetite 2016, 101, 1-7. [CrossRef]

61. Thong, F.S.L.; Hudson, R.; Ross, R.; Janssen, I.A.N.; Graham, T.E. Plasma leptin in moderately obese men: Independent effects of weight loss and aerobic exercise. Am. J. Physiol. Endocrinol. Metab. 2000, 279, 307-313. [CrossRef] [PubMed]

62. Chin-Chance, C.; Polonsky, K.S.; Schoeller, D.A. Twenty-Four-Hour Leptin Levels Respond to Cumulative Short-Term Energy Imbalance and Predict Subsequent Intake1. J. Clin. Endocrinol. Metab. 2000, 85, 2685-2691. [CrossRef] [PubMed]

63. Herrmann, T.S.; Bean, M.L.; Black, T.M.; Wang, P.; Coleman, R.A. High glycemic index carbohydrate diet alters the diurnal rhythm of leptin but not insulin concentrations. Exp. Biol. Med. 2001, 226, 1037-1044. [CrossRef]

64. Poppitt, S.D.; Leahy, F.E.; Keogh, G.F.; Wang, Y.; Mulvey, T.B.; Stojkovic, M.; Chan, Y.K.; Choong, Y.S.; McArdle, B.H.; Cooper, G.J.S. Effect of high-fat meals and fatty acid saturation on postprandial levels of the hormones ghrelin and leptin in healthy men. Eur. J. Clin. Nutr. 2006, 60, 77-84. [CrossRef]

65. Bray, G.A.; Most, M.; Rood, J.; Redmann, S.; Smith, S.R. Hormonal responses to a fast-food meal compared with nutritionally comparable meals of different composition. Ann. Nutr. Metab. 2007, 51, 163-171. [CrossRef]

66. Carlson, O.; Martin, B.; Stote, K.S.; Golden, E.; Maudsley, S.; Najjar, S.S.; Ferrucci, L.; Ingram, D.K.; Longo, D.L.; Rumpler, W.V.; et al. Impact of reduced meal frequency without caloric restriction on glucose regulation in healthy, normal-weight middle-aged men and women. Metab. Clin. Exp. 2007, 56, 1729-1734. [CrossRef] [PubMed]

67. Abete, I.; Parra, D.; Crujeiras, A.B.; Goyenechea, E.; Martínez, J.A. Specific insulin sensitivity and leptin responses to a nutritional treatment of obesity via a combination of energy restriction and fatty fish intake. J. Hum. Nutr. Diet. 2008, 21, 591-600. [CrossRef]

68. Nedeltcheva, A.V.; Kilkus, J.M.; Imperial, J.; Kasza, K.; Schoeller, D.A.; Penev, P.D. Sleep curtailment is accompanied by increased intake of calories from snacks. Am. J. Clin. Nutr. 2009, 89, 126-133. [CrossRef] 
69. Bortolotti, M.; Kreis, R.; Debard, C.; Cariou, B.; Faeh, D.; Chetiveaux, M.; Ith, M.; Vermathen, P.; Stefanoni, N.; Lê, K.A.; et al. High protein intake reduces intrahepatocellular lipid deposition in humans. Am. J. Clin. Nutr. 2009, 90, 1002-1010. [CrossRef] [PubMed]

70. Ratliff, J.; Mutungi, G.; Puglisi, M.J.; Volek, J.S.; Fernandez, M.L. Carbohydrate restriction (with or without additional dietary cholesterol provided by eggs) reduces insulin resistance and plasma leptin without modifying appetite hormones in adult men. Nutr. Res. 2009, 29, 262-268. [CrossRef] [PubMed]

71. Cooper, J.A.; Polonsky, K.S.; Schoeller, D.A. Serum leptin levels in obese males during over-and underfeeding. Obesity 2009, 17, 2149-2154. [CrossRef]

72. Adachi, T.; Sert-Kuniyoshi, F.H.; Calvin, A.D.; Singh, P.; Romero-Corral, A.; Van Der Walt, C.; Davison, D.E.; Bukartyk, J.; Konecny, T.; Pusalavidyasagar, S.; et al. Effect of weight gain on cardiac autonomic control during wakefulness and sleep. Hypertension 2011, 57, 723-730. [CrossRef] [PubMed]

73. Lecoultre, V.; Ravussin, E.; Redman, L.M. The fall in leptin concentration is a major determinant of the metabolic adaptation induced by caloric restriction independently of the changes in leptin circadian rhythms. J. Clin. Endocrinol. Metab. 2011, 96, E1512-E1516. [CrossRef] [PubMed]

74. Varady, K.A.; Bhutani, S.; Klempel, M.C.; Phillips, S.A. Improvements in vascular health by a low-fat diet, but not a high-fat diet, are mediated by changes in adipocyte biology. Nutr. J. 2011, 10, 8. [CrossRef]

75. Ebbeling, C.B.; Swain, J.F.; Feldman, H.A.; Wong, W.W.; Hachey, D.L.; Garcia-Lago, E.; Ludwig, D.S. Effects of dietary composition on energy expenditure during weight-loss maintenance. JAMA J. Am. Med. Assoc. 2012, 307, 2627-2634. [CrossRef]

76. Chang, K.T.; Lampe, J.W.; Schwarz, Y.; Breymeyer, K.L.; Noar, K.A.; Song, X.; Neuhouser, M.L. Low glycemic load experimental diet more satiating than high glycemic load diet. Nutr. Cancer 2012, 64, 666-673. [CrossRef] [PubMed]

77. Varady, K.A.; Bhutani, S.; Klempel, M.C.; Kroeger, C.M.; Trepanowski, J.F.; Haus, J.M.; Hoddy, K.K.; Calvo, Y. Alternate day fasting for weight loss in normal weight and overweight subjects: A randomized controlled trial. Nutr. J. 2013, 12, 146. [CrossRef] [PubMed]

78. Calvin, A.D.; Carter, R.E.; Adachi, T.; MacEdo, P.G.; Albuquerque, F.N.; Van Der Walt, C.; Bukartyk, J.; Davison, D.E.; Levine, J.A.; Somers, V.K. Effects of experimental sleep restriction on caloric intake and activity energy expenditure. Chest 2013, 144, 79-86. [CrossRef] [PubMed]

79. Mendham, A.E.; Duffield, R.; Marino, F.; Coutts, A.J. Small-sided games training reduces CRP, IL-6 and leptin in sedentary, middle-aged men. Eur. J. Appl. Physiol. 2014, 114, 2289-2297. [CrossRef]

80. Singh, P.; Sharma, P.; Sahakyan, K.R.; Davison, D.E.; Sert-Kuniyoshi, F.H.; Romero-Corral, A.; Swain, J.M.; Jensen, M.D.; LopezJimenez, F.; Kara, T.; et al. Differential effects of leptin on adiponectin expression with weight gain versus obesity. Int. J. Obes. 2016, 40, 266-274. [CrossRef]

81. Perrigue, M.M.; Drewnowski, A.; Wang, C.Y.; Song, X.; Kratz, M.; Neuhouser, M.L. Randomized Trial Testing the Effects of Eating Frequency on Two Hormonal Biomarkers of Metabolism and Energy Balance. Nutr. Cancer 2017, 69, 56-63. [CrossRef] [PubMed]

82. Liu, G.; Liang, L.; Bray, G.A.; Qi, L.; Hu, F.B.; Rood, J.; Sacks, F.M.; Sun, Q. Thyroid hormones and changes in body weight and metabolic parameters in response to weight loss diets: The POUNDS LOST trial. Int. J. Obes. 2017, 41, 878-886. [CrossRef] [PubMed]

83. Kessler, K.; Hornemann, S.; Petzke, K.J.; Kemper, M.; Markova, M.; Rudovich, N.; Grune, T.; Kramer, A.; Pfeiffer, A.F.H.; Pivovarova-Ramich, O. Diurnal distribution of carbohydrates and fat affects substrate oxidation and adipokine secretion in humans. Am. J. Clin. Nutr. 2018, 108, 1209-1219. [CrossRef] [PubMed]

84. Trepanowski, J.F.; Kroeger, C.M.; Barnosky, A.; Klempel, M.; Bhutani, S.; Hoddy, K.K.; Rood, J.; Ravussin, E.; Varady, K.A. Effects of alternate-day fasting or daily calorie restriction on body composition, fat distribution, and circulating adipokines: Secondary analysis of a randomized controlled trial. Clin. Nutr. 2018, 37, 1871-1878. [CrossRef] [PubMed]

85. Hołowko, J.; Michalczyk, M.M.; Zajac, A.; Czerwińska-Rogowska, M.; Ryterska, K.; Banaszczak, M.; Jakubczyk, K.; Stachowska, E. Six weeks of calorie restriction improves body composition and lipid profile in obese and overweight former athletes. Nutrients 2019, 11, 1461. [CrossRef] [PubMed]

86. Benbaibeche, H.; Bounihi, A.; Koceir, E.A. Leptin level as a biomarker of uncontrolled eating in obesity and overweight. Ir. J. Med. Sci. 2020, 190, 155-161. [CrossRef]

87. Poetsch, M.S.; Strano, A.; Guan, K. Role of Leptin in Cardiovascular Diseases. Front. Endocrinol. 2020, 11, 354. [CrossRef] [PubMed]

88. Reyes-Barrera, J.; Sainz-Escárrega, V.H.; Medina-Urritia, A.X.; Jorge-Galarza, E.; Osorio-Alonso, H.; Torres-Tamayo, M.; LealEscobar, G.; Posadas-Romero, C.; Torre-Villalvazo, I.; Juárez-Rojas, J.G. Dysfunctional adiposity index as a marker of adipose tissue morpho-functional abnormalities and metabolic disorders in apparently healthy subjects. Adipocyte 2021, 10, 142-152. [CrossRef] [PubMed]

89. Trinh, T.; Broxmeyer, H.E. Role for Leptin and Leptin Receptors in Stem Cells During Health and Diseases. Stem Cell Rev. Rep. 2021, 17, 511-522. [CrossRef] [PubMed]

90. Thackray, A.E.; Willis, S.A.; Clayton, D.J.; Broom, D.R.; Finlayson, G.; Goltz, F.R.; Sargeant, J.A.; Woods, R.M.; Stensel, D.J.; King, J.A. Influence of short-term hyperenergetic, high-fat feeding on appetite, appetite-related hormones, and food reward in healthy men. Nutrients 2020, 12, 2635. [CrossRef] [PubMed]

91. Fantuzzi, G. Adiponectin in inflammatory and immune-mediated diseases. Cytokine 2013, 64, 1-10. [CrossRef] [PubMed] 
92. Ouchi, N.; Walsh, K. Adiponectin as an anti-inflammatory factor. Clin. Chim. Acta 2007, 380, 24-30. [CrossRef]

93. Arch, J.R.S. The discovery of drugs for obesity, the metabolic effects of leptin and variable receptor pharmacology: Perspectives from 33- adrenoceptor agonists. Naunyn Schmiedebergs Arch. Pharmacol. 2008, 378, 225-240. [CrossRef] [PubMed]

94. Zanella, M.T.; Filho, F.F.R. Novos fármacos para o tratamento da obesidade. Arq. Bras. Endocrinol. Metabol. 2009, 53, 271-280. [CrossRef]

95. Cassioli, E.; Rossi, E.; Squecco, R.; Baccari, M.C.; Maggi, M.; Vignozzi, L.; Comeglio, P.; Gironi, V.; Lelli, L.; Rotella, F.; et al. Reward and psychopathological correlates of eating disorders: The explanatory role of leptin. Psychiatry Res. 2020, $290,113071$. [CrossRef] [PubMed]

96. Platzer, M.; Fellendorf, F.T.; Bengesser, S.A.; Birner, A.; Dalkner, N.; Hamm, C.; Lenger, M.; Maget, A.; Pilz, R.; Queissner, R.; et al. The relationship between food craving, appetite-related hormones and clinical parameters in bipolar disorder. Nutrients 2020, 13, 76. [CrossRef]

97. Steiner, J.; Bernstein, H.G.; Guest, P.C.; Summergrad, P.; Oxenkrug, G. Plasma leptin correlates with anthranilic acid in schizophrenia but not in major depressive disorder. Eur. Neuropsychopharmacol. 2020, 41, 167-168. [CrossRef] [PubMed]

98. Tural, R.; Altan, N.; Irkec, C.; Sahin, D.; Batur Caglayan, H.Z. The probable role of insulin resistance and SIRT1 proteins in the Alzheimer's disease. Bratisl. Lek. Listy 2020, 121, 812-816. [CrossRef] [PubMed]

99. Guzmán, A.; Hernández-Coronado, C.G.; Rosales-Torres, A.M.; Hernández-Medrano, J.H. Leptin regulates neuropeptides associated with food intake and GnRH secretion. Ann. Endocrinol. 2019, 80, 38-46. [CrossRef]

100. Marcos, P.; Coveñas, R. Neuropeptidergic control of feeding: Focus on the galanin family of peptides. Int. J. Mol. Sci. 2021, 22, 2544. [CrossRef] [PubMed] 